NBER WORKING PAPER SERIES

BYE, BYE, MISS AMERICAN PIE? THE SUPPLY OF NEW RECORDED MUSIC SINCE NAPSTER

Joel Waldfogel

Working Paper 16882

http://www.nber.org/papers/w16882

\author{
NATIONAL BUREAU OF ECONOMIC RESEARCH \\ 1050 Massachusetts Avenue \\ Cambridge, MA 02138 \\ March 2011
}

The title refers to Don McLean's song, American Pie, which chronicled a catastrophic music supply shock, the 1959 crash of the plane carrying Buddly Holly, Richie Valens, and Jiles Perry "The Big Bopper" Richardson, Jr. The song's lyrics include, "I saw Satan laughing with delight/The day the music died." I am grateful to seminar participants at the Carlson School of Management and the WISE conference in St. Louis for questions and comments on a presentation related to an earlier version of this paper. The views expressed in this paper are my own and do not reflect the positions of the National Academy of Sciences' Committee on the Impact of Copyright Policy on Innovation in the Digital Era or those of the National Bureau of Economic Research.

NBER working papers are circulated for discussion and comment purposes. They have not been peerreviewed or been subject to the review by the NBER Board of Directors that accompanies official NBER publications.

(C) 2011 by Joel Waldfogel. All rights reserved. Short sections of text, not to exceed two paragraphs, may be quoted without explicit permission provided that full credit, including $\odot$ notice, is given to the source. 
Bye, Bye, Miss American Pie? The Supply of New Recorded Music Since Napster

Joel Waldfogel

NBER Working Paper No. 16882

March 2011

JEL No. K11,L82

\begin{abstract}
$\underline{\text { ABSTRACT }}$
In the decade since Napster, file-sharing has undermined the protection that copyright affords recorded music, reducing recorded music sales. What matters for consumers, however, is not sellers' revenue but the surplus they derive from new music. The legal monopoly created by copyright is justified by its encouragement of the creation of new works, but there is little evidence on this relationship. The file-sharing era can be viewed as a large-scale experiment allowing us to check whether events since Napster have stemmed the flow of new works. We assemble a novel dataset on the number of high quality works released annually, since 1960, derived from retrospective critical assessments of music such best-of-the-decade lists. This allows a comparison of the quantity of new albums since Napster to 1) its pre-Napster level, 2) pre-Napster trends, and 3) a possible control, the volume of new songs since the iTunes Music Store's revitalization of the single. We find no evidence that changes since Napster have affected the quantity of new recorded music or artists coming to market. We reconcile stable quantities in the face of decreased demand with reduced costs of bringing works to market and a growing role of independent labels.
\end{abstract}

\title{
Joel Waldfogel
}

Frederick R. Kappel Chair in Applied Economics

3-177 Carlson School of Management

University of Minnesota

321 19th Avenue South

Minneapolis, MN 55455

and NBER

jwaldfog@umn.edu 
The decade since Napster has seen a stark drop in revenue to the recorded music industry that many observers attribute to file sharing. Between 1999 and 2008, annual revenue from physical recorded music products fell from $\$ 12.8$ billion to $\$ 5.5$ billion in the US after nearly continuous increases over the previous decades. ${ }^{1}$ Even with digital sales included, US revenue was a third below its 1999 level. The decline is not confined to the US: Worldwide revenue from physical recorded music fell from $\$ 37$ billion in 1999 to $\$ 25$ billion in 2007. The struggles of the recorded music industry have spawned practioner, policy maker, and academic debates over the role of unauthorized file sharing. ${ }^{2}$ Although it is still controversial in some circles, most observers agree that file sharing is responsible for much if not most of the reduction in revenue to the recorded music industry. To put this another way, most observers agree that technological change since the late 1990s has sharply reduced effective copyright protection for music.

Organizations representing the recording industry have argued vigorously that piracy will have serious consequences for whether new works will be brought to market and made available to consumers. According to the International Federation of the Phonographic Industry (IFPI), "[m]usic is an investment-intensive business... Very few sectors have a comparable proportion of sales to R\&D investment to the music industry." But, according to a Warner Music official, "piracy makes it more difficult for the whole industry to sustain that regular investment in breaking talent." ${ }^{3}$ The Recording Industry Association of America voices similar concerns: "Our goal with all these anti-piracy efforts is to protect the ability of the recording industry to invest in new bands and new music..." And: "this theft has hurt the music community, with

\footnotetext{
${ }^{1}$ See http://www.riaa.com/keystatistics.php?content_selector=keystats_yearend_report, accessed April 28, 2010. Also, see Leibowitz (2006).

${ }^{2}$ Oberholzer-Gee and Strumpf (2006) initiated the contemporary empirical debate over file sharing. See also Rob and Waldfogel (2006), Blackburn (2004), Zentner (2006), among others.

${ }^{3}$ See http://www.ifpi.org/content/section_news/investing_in_music.html, accessed October 20, 2010.
} 
thousands of layoffs, songwriters out of work and new artists having a harder time getting signed and breaking into the business."

While the question of whether file sharing displaces legal sales and weakens copyright is an interesting academic question - and vital for the recorded music industry - it is arguably not the most important question about copyright raised by new technology. Copyright has traditionally allowed the recording industry to get revenue from music sold on CDs. If economic returns provide the incentive for producers to make music, then factors threatening the ability of copyright to protect intellectual property may reduce the quantity of new recorded music. File sharing is not the only consequence of technological change affecting music since Napster. New developments in computer and communications (e.g. the Internet) may also have reduced costs of creating, distributing, and promoting new recorded music. While much existing research focuses on the effect of file sharing on demand for legal recorded music, the more important question for the well-being of consumers is whether the overall effect of recent technological changes has reduced quantity of consequential music brought to market. ${ }^{5}$ We can use the piracy decade as a compound experiment to ask whether reduced returns, in conjunction with potentially reduced costs, have stemmed the avalability of new music.

Economists generally agree that monopolies are bad. ${ }^{6}$ Governments grant some of the basic textbook examples of monopolies for intellectual property, in the form of patents and copyrights. Their bad effects - allowing prices above marginal costs and therefore restricting

\footnotetext{
${ }^{4}$ See http://www.riaa.com/physicalpiracy.php, accessed October 20, 2010.

${ }^{5}$ These questions have not escaped inquiry entirely. See Handke $(2006,2009)$ and Oberholzer-Gee and Strumpf (2009), which we discuss further below.

${ }^{6}$ Boldrin and Levine (2008) remind us of this point in the specific context of protections for intellectual property. They also make the point, with interesting historical references, that music was produced for hundreds of years without intellectual property protection.
} 
the supply of output - are thought to be justified by their incentive effects on production. But apart from introspection and anecdotes, we don't really know much about the effects of remuneration incentives on production in the music industry. Paul McCartney recounts a famous story that John Lennon, while remodelling his house, said to Paul, “OK! Today, let's write a swimming pool." And Paul continued, "It was a great motivation.", But is the lesson of this anecdote true more generally? Does the prospect of greater rewards bring forth more music? If so, then unless other factors offset the reduced revenue, the past decade should have been a dry period for music. This is the question we address in this study.

Characterizing the volume of creative products is difficult, particularly if one's goal is quantify the effect of new products on welfare. The most natural measure - the number of new recordings available for sale - is quite imperfect. First, there is intense skew in the sales distribution for recorded music, making the link between the number of products and welfare unclear. New technologies have reduced the cost of creating new works, and the number of new recordings available has increased substantially. Yet - now as before - the vast majority of these products sell very few copies, casting doubt on whether the number of new works made available for sale would be proportional to welfare.

A natural second impulse is to want detailed data on prices and quantities of music purchased, along with other data, for estimating demand systems for calculating the consumer and surplus from new music. But even this approach faces a daunting challenge: Because of file sharing, an album of equal notional appeal released today rather than 15 years ago generates far

\footnotetext{
${ }^{7}$ See "McCartney + Lennon Wrote Swimming Pool." Contact Music, 23 August, 2005. (http://www.contactmusic.com/new/xmlfeed.nsf/story/mccartney-t-lennon-wrote-swimming-pool-song, accessed October 8, 2010).
} 
less realized demand, simply because the willingness to pay has diminished in the face of unpaid alternatives. Hence, the surplus implied by a demand system estimated in the file sharing era will understate the contribution of new products to welfare.

What we want is a measure of the number of products whose appeal surpasses some time-constant threshold. The index of appeal should be related to demand, but the index must be unaffected by file sharing so that it can be used to create an index of the supply of new creative goods over time, including during the era of unpaid consumption. That is, we cannot quantify supply with, say, the number of albums selling more than 5000 copies. If file sharing undermines purchase incentives, then an album needs to be better now to garner 5000 sales than 15 years ago.

Our proposed solution to this conundrum is a time-constant quality threshold based on critics' retrospective lists of the best works of multi-year time periods. Our measure of new products is the number of albums released each year that surpass one of various quality thresholds based on critics' reviews. To quantify this, we have assembled data on album quality from 88 Anglophone sources, chiefly from retrospective lists (e.g. Rolling Stone's 500 best albums, Pitchfork Media's 200 best albums of the 1990s, etc.). Each of these rankings allows us to create an index of the number of albums released each year meeting the criterion. Because use of these data to measure new products is novel, we devote some effort to justifying the approach. We show that the indices are highly correlated with each other and that indices reflect wellknown facts about the history of popular music. We also demonstrate that albums that are more highly regarded by critics sell more, which indicates that the indices are not simply reflective of critics' esoteric tastes. Instead, these indices provide a measure of the quantity of new work that 
is relevant to consumer and producer surplus but whose meaning is not undermined by file sharing. We use simple regression models to splice these indices together to produce overall indices of new, consequential albums (and songs) since 1960. We document the evolution of the album index surrounding Napster, and we also measure its movement relative to a plausible control, new songs since the 2003 launch of the iTunes Music Store.

The study proceeds in three sections. Section 1 provides the theoretical background linking file sharing to the well-being of consumers and producers in the short and longer run. Section 2 describes the various data sources employed in the study, along with evidence supporting our use of such data to measure music supply. Section three then reports our main results. Using indices collectively covering the period since 1960, we document that the annual number of new albums passing various quality thresholds has remained roughly constant since Napster, is statistically indistinguishable from pre-Napster trends, and has not diverged from song supply since iTunes' revival of the single format in 2003 . We also document that the role of new artists in new recorded music products has not diminished since Napster. We offer a reconcilation of a stable quantity of acclaimed new products in the face of diminished demand with evidence of an outward shift in supply, reflecting reduced costs of bringing new works to market. We conclude with a discussion of what the results do - and do not - mean.

\section{Welfare from Music}

1. Static and Dynamic Welfare Analysis 
Like any product, music generates surplus for two parties, buyers and sellers. While recorded music is durable in some senses - the recordings can last forever and can be reproduced digitally without degradation in quality - it is subject to taste depreciation. Obviously, there are exceptions. Many people still listen to classical music that is hundreds of years old. But for the most part, consumers prefer new music. There is direct evidence that music depreciates in Rob and Waldfogel (2006): consumers attach lower value to popular music, the longer they have owned it. ${ }^{8}$

The possibility that music depreciates is important for a welfare analysis of supply disruptions. If it did not, then the consumer losses from a disruption to new supply would be of only second-order importance. If the amount of music available increased a few percent in a normal year, then a complete cessation of new production would still leave consumers with nearly as much variety as they would have faced if new products had continued to arrive. If additional varieties are substitutes for existing varieties, then under usual assumptions about marginal utility in the face of multiple varieties, the failure to add relatively small numbers of products to the existing stock of available products would have small effects on welfare. But because most music does seem to depreciate for most users, disruptions to supply are potentially important for the welfare that this product delivers.

The welfare analysis of sharing zero-marginal-cost digital products has two parts, which could be termed static and dynamic. The static analysis describes music that already exists. It is easy to see that file sharing simply increases welfare. Producers lose, but their losses - when

\footnotetext{
${ }^{8}$ There is interesting variation across works' depreciation rates. Rob and Waldfogel (2006) estimate that the value that survey respondents attached to a Beatles album appreciated 26 percent per year of ownership while a Britney Spears album depreciated 28 percent annually.
} 
consumers steal things they used to pay for - are all transfers to consumers, who now enjoy greater surplus (the price they had formerly paid plus the former consumer surplus). In addition to the transfers from producers to consumers, file sharing also turns deadweight loss circumstances in which consumers valued music above zero but below its price and therefore did not consume - into consumer surplus. In a purely static analysis, eliminating intellectual property rights benefits consumers more than it costs producers and is therefore beneficial for society.

Of course, the static analysis above is valid only for works that already exist. The dynamic analysis is different. If developing products requires investments of time or money, then producers may only make these investments in the hopes of obtaining returns. If the returns are eliminated, then producers may stop investing. If music fully depreciates in one period, then there is no supply available in the second period, and there is no surplus for either party. In contrast to the welfare-improving static effects of file sharing on welfare, the dynamic impact is potentially devastating. Despite recent concern about new works since Napster, we have little evidence on whether the quantity of economically consequential work has declined since Napster. This is the question we now turn to.

\section{Measuring Supply}

At first blush the obvious way to measure the supply of recorded music is with the number of songs or albums available. By extension, the new supply is the number of new songs or albums available in, say, a given year. Oberholzer-Gee and Strumpf (2009) and Handke 
(2006, 2010) point to evidence that the number of albums released in the US and Germany - and that the number of labels operating in Germany - have not declined in the past decade to argue that file sharing has not interrupted the flow of new works. While this evidence is quite interesting, one might be concerned about that the great skew in the sales distribution undermines proportionality - and perhaps even the monotonicity - between titles and welfare. According to SoundScan, there were 97,751 new albums released in 2009, but only 2050 sold over 5000 units. $^{9}$ Thus, the amount of surplus generated is not proportional to the number of products made available, so the number of products provides an incomplete measure of the welfare effects of new works. ${ }^{10}$ And while the evidence on the number of recording labels operating is quite interesting - more on this below at section IV - it is not by itself a measure of the amount of surplus that recorded music generates for consumers or producers.

An alternative approach is to measure the flow of new works as the number of albums that meet some importance threshold. For example, it might be informative to examine the number of albums selling over 5000 copies in a year. Apart from the fact that those data are hard to come by, it too seems potentially misleading. If we accept that sales are falling over time because of growth in unpaid consumption, then the threshold would have to vary over time for the number of albums above the threshold to maintain its meaning. We don't really know either the threshold nor its rate of decline, so this method does not seem promising. As argued in the

\footnotetext{
${ }^{9}$ See Glenn Peoples. “Analysis: Important Sales Trends You Need to Know.” Billboard.Biz, June 2, 2010.

${ }^{10}$ Variation in the number of new titles from one year to the next can also provide a misleading measure of new production. The number of new albums in SoundScan fell from 105,000 in 2008 to 97,751 in 2009 because "in recent years, digital distributors flooded online retail with foreign catalogs being licensed to new territories. In effect, these distributors are catching up to all the music that's available from around the world....this won't go on forever. As fewer and fewer old recordings find their way to U.S. retailers for the first time, the unique number of titles released in a given year will fall." See Peoples (2010).
} 
introduction, estimating a demand system for purchases of recorded music would also not circumvent this problem.

While traditional approaches to quantifying the welfare effects of new products are stymied by the growth of piracy, there are other ways of quantifying the number of new albums meeting some importance threshold each year. Both professional and amateur music listeners are in the habit of rating and ranking their music. We can use these ratings and rankings as thresholds. We can then ask what is happening to the quantity of new music meeting any particular threshold over time.

\section{Data and Reliability}

\section{Sources}

The basic data for this study are professional critics' retrospective rankings of songs and albums from multiple years, such as "best-of-the-decade" lists. For these lists, the staff of a magazine or website produce a list of the best albums (or songs) of the past decade, or quarter century, or all time. That is, experts evaluate music from different years, subjecting all of it to a time-constant quality threshold for list inclusion. Prominent examples include Rolling Stone's 2004 list of the 500 best albums or Pitchfork Media's list of best 200 albums of the 2000s (see the Appendix Table 1 for a full list of the sources and their coverage). We have 88 different 
rankings (and ratings), 64 covering albums and the remainder covering songs. All of the rankings are from Anglophone countries (the US, England, Canada, and Ireland). ${ }^{11}$

These rankings generate data of the form: $\mu_{1}>\ldots>\mu_{N}$, where $\mu_{i}$ is the quality of work $i$. If $T_{k}$ is a quality threshold such that $\mu_{k}>T_{k}>\mu_{k+1}$, then each of these rankings allows us to calculate the number of works above a constant $T_{k}$ released in each year. These rankings allow ready creation of indices showing the volume of works released in each year that pass some threshold.

For example, Rolling Stone released its 500 best albums list in 2004. Entries on the "were chosen by 273 of the world's pre-eminent musicians and critics ranging from Fats Domino to Moby" (Levy 2005). Figure 1 depicts the supply index derived from Rolling Stone's list, and a few things are immediately evident. First, perhaps because Rolling Stone was founded in 1967, its editors are very fond of 1960s music. Second, the index trails off toward the year that the list appeared (2004). This may arise partly mechanically from the process of ranking: rankings released in a given year may be the result of a process begun a year earlier.

Most of our indices are based on retrospective lists, which - unlike ongoing reviews allow their creators some chronological perspective on the works they rank. By construction, however, these rankings are assembled close to the last year of the period evaluated, giving rank creators less time to assess recent works. This gives rise to a bias against recent works in these rankings. For example, Pitchfork Media produced a list of the top 100 albums of the 1990s in October 1999, then another list covering the same period in November 2003. The latter list was

\footnotetext{
${ }^{11}$ We discovered rankings in a variety of places. The Acclaimed Music website lists many of these, including the majority of the lists we use for the period since 1999. See, in particular, the lists of the top albums and songs of the 2000s at http://www.acclaimedmusic.net/, accessed December 21, 2010.
} 
introduced with a statement contrasting it with their 1999 ranking, “...looking back at that list a lot has changed: our perceptions of the decade are different now, our personal tastes have expanded, our knowledge of the music has deepened..."12 And, indeed, the later ranking includes a greater emphasis on the last years of the decade. Ten percent of the albums on the 2003 list were released in the last two years of the decade, compared with only seven percent for the 1999 list. Hence, we can use the retrospective rankings but exclude the year the ranking appeared as well as the previous year to avoid a bias against recent works.

The contemporaneous ratings reported at Metacritic provide a second sort of quality data. Metacritic translates reviews from multiple sources into a unified 100-point scale. ${ }^{13}$ Reviews appear in Metacritic only when an album has been reviewed by at least three of the underlying sources that Metacritic incorporates. These sites do not review all of the albums released. Estimates of the number of new albums each year vary between 30,000 and 100,000; regardless, Metacritic produces reviews of only a small fraction. If the method for choosing albums for review were constant over time - so that an album of given quality were equally likely to be reviewed regardless of release year - then the number of albums passing a quality threshold would provide a clean measure of the quantity of new works exceeding some quality threshold. But album selection rules change over time, and the number of albums reviewed has grown steadily from 222 to nearly 500 from 2000 to 2007 , then jumped roughly 60 percent in $2008 .{ }^{14}$

\footnotetext{
${ }^{12} \mathrm{See} \mathrm{http://pitchfork.com/features/staff-lists/5923-top-100-albums-of-the-1990s/,} \mathrm{accessed} \mathrm{October} \mathrm{18,} 2010$.

13 "Metacritic's proprietary Metascore distills the opinions of the most respected critics writing online and in print to a single number." See http://www.metacritic.com/about-metacritic , accessed October 8, 2010.

${ }^{14}$ Metacritic's database includes 222 reviews from 2000, 300 for 2001, 362 for 2002, 429 for 2003, 457 for 2004, 477 for 2005, 506 for 2006, 486 for 2007, 805 for 2009, 976 for 2010, and 522 for 2010 (as of October 18, 2010). These figures are from http://apps.metacritic.com/search/index.shtml, accessed October 18, 2010.
} 
Using Metacritic's all time best list, I have obtained the roughly 4700 albums that have received Metacritic scores above 61 between 2000 and late 2010. I calculate an index from the number of such albums released each year, then divide the index by the number of albums that Metacritic reviewed each year.

A third source of ranking/rating information might be termed wiki ratings. These begin with Zagat's survey based ranking of the top 1000 albums, released in 2003. Their list was based on a survey of 10,600 survey respondents who listened "to an average of 24.2 hours of music per week." Because Zagat's ranking book as published in September 2003, we exclude 2003 from the Zagat data for the mechanical reason that respondents cannot possibly have included as many 2003 albums. We also exclude 2002 to deal with the anti-recency bias discussed above.

Recently, various websites have emerged where users - amateur music aficionados upload their rankings or ratings of music. Such sites include BestEver.com, where users upload their rankings, typically their top 50. As of October 2010, nearly 1900 individuals had uploaded their rankings. At RateYourMusic.com, users enter ratings of songs. Based on these user ratings, the sites produce rankings, for example the top 1000 albums of all time. A challenge with these rankings, particularly the latter two, is that users upload their rankings at different times. If a user uploaded his ranking in 2006, it will clearly not include works from subsequent years (and may not yet include recent works either). The overall rankings, aggregating rankings produced in different years, do not adjust for the different exposure of recent works, i.e. their depressed possibility of being included in users' rankings. The only "fair" comparisons from such rankings is over periods when all works are at risk of being included, that is the period prior 
to when the first user made his ranking. RateYourMusic.com was founded in December $2000{ }^{15}$ Bestever albums.com was founded in 2005. ${ }^{16}$ Thus, these sources' overall rankings are valid only through 2000 and 2004, respectively.

A final sort of ranking that does not fit neatly into the scheme above are the list at Acclaimed Music, a site operated by a Swedish statistician who synthesizes over 100 different professional music critics' rankings to produce overall rankings of the top 3000 albums, and songs, of all time. ${ }^{17}$ Acclaimed Music also produces rankings of the top albums - and top songs - of the decade 2000-2009, and they provide the underlying individual critical outlets' best-of lists, which we use directly. These included 56 album lists and 22 song lists from US, Canadian, and UK sources. ${ }^{18}$ Together, the 64 album lists cover the period 1960-2007 and include 15,158 entries. The 24 song lists also cover 1960-2007 and include 1806 entries.

\section{Data Validation}

The first question we need to address is whether the data measure something meaningful. We would like to advance the interpretation that the data - on the number of songs or albums above some critics' threshold released in a year - provide a reasonable measure of supply. We can subject these indices to various tests of legitimacy. First, we can ask whether they track well-known historical trends in music. For example, historians of contemporary popular music

\footnotetext{
${ }^{15}$ See http://en.wikipedia.org/wiki/Rate_Your_Music, accessed October 20, 2010.

${ }^{16} \mathrm{See}$ http://www.besteveralbums.com/howitworks.php, accessed October 20, 2010.

${ }^{17}$ See the "Questions \& Answers" page at http://www.acclaimedmusic.net/, accessed October 27, 2010.

${ }^{18} \mathrm{We}$ exclude lists that do not cover rock music generally. Thus, we exclude terrorizer (a metal-only list), the Times Jazz and World lists, and so on.
} 
believe that the late 1960 s was a period of unparalleled creative output in recorded music. ${ }^{19}$ Do the indices reflect this?

Figure 2 shows the number of top albums released in each year from five separate rankings covering a long sweep of the history of rock music, Rolling Stone, Zagat, Rate Your Music, Acclaimed Music, and the BestEver site. All show spikes in the late 1960s, as well as a second spike in the mid-1990s. The Rolling Stone list is more heavily skewed toward the 1960s, relative to the other two, but all five provide some reflection that both the late 1960s and the early-to-mid 1990s were fertile periods for music. A second question is whether the indices are similar to each other. If the late 1960s was in fact an important period, then all indices should reflect this. Of the indices in Figure 2, all pairwise correlations exceed 0.7, except the correlations with Zagat (which lie between 0.05 and 0.53 ).

That the different indices, dervied from independent assessments of music, are highly correlated provides some reassurance that the indices measure something meaningful about the each year's contribution to the supply of music. Moreover, the high correlations between indices based on amateurs' rankings (such as Zagat and, especially, BestEver and Rate Your Music) and indices based on professional critics' rankings (Rolling Stone and Acclaimed Music) provide evidence that the indices reflect recorded music products with broad appeal. However, the variation in musical output over time also suggests a caution: because there were no changes in the returns to creating music in the periods of high output, it appears that supply varies over time for reasons unrelated to the incentive effects we seek to examine in this study.

\footnotetext{
${ }^{19}$ For example, Larkin (2007) writes, "The 60s will remain, probably forever, the single most important decade for popular music."
} 
Because the period following 1999 is crucial to this study, it is important to provide evidence of the reasonableness of the rankings and resulting indices for the post-1999 period. We have 56 professional critics' album lists - and 22 professionals' songs lists - covering this period (beginning in 2000). To determine whether these lists contain a common signal rather than simply noise, we do a few things. First, we examine overlap across lists.

Table 1 shows the albums appearing on the most lists. Two albums - Funeral by Arcade Fire and Kid A by Radiohead appear on 47 of the 56 lists covering the 2000s. Is this It? by the Strokes and Stankonia by Outkast appear on 45 and 37 lists, respectively. Figure 3 shows the overlap across lists more systematically, via an album Lorenz curve: 100 albums account for 40 percent of the entries on decade-best lists, 250 albums account for over 60 percent, and 500 albums account for over three quarters of the 4202 entries on 56 publications' best-of-the-2000s lists. At least 300,000 albums were released during the decade. Yet, 500 albums - less than $0.2 \%$ of the decade's new releases - account for three quarters of the entries on 56 critical best of the 2000s lists. Table 2 and Figure 4 repeat the exercise for songs, which exhibit a similarly substantial degree of overlap across the 22 song lists for the 1990s. The concordance far exceeds what would arise by chance and suggests a large systematic component to the determination of critics' rankings.

\section{High Rankings and Sales}

If the designation of being an acclaimed album is meaningful - relevant to whether the album's existence and consumption generated extra satisfaction for consumers - then critically 
acclaimed albums should sell more. That is, our measure of supply should be relevant to the generation of additional economic surplus. While album sales data are generally difficult for researchers to obtain, one source of approximate US album sales data is the RIAA certifications. An album is certified "gold" with 0.5 million sales and "platinum" with 1 million. As sales pass the second or third million, etc., they receive additional "multi-platinum" certifications. The certifications thus allow the creation of a dataset with all albums over 0.5 million in sales, with categoric sales measures: 0.5 corresponds to sales between 500,000 and 1 million, 1 million corresponds to sales between 1 and 2 million, and so on. Critical acclaim and sales are linked. The most acclaimed albums of the 2000-2009 decade, in Table 1, also tend to have sold rather well. Half of the 50 albums on the list sold at least half a million copies.

We can explore this more systematically as well. The RIAA certifications data are available online, and I merged a dataset consisting of the cumulative sales of the 7700 certified albums as of 2004 with the Zagat (2004) album ratings. Zagat includes 1000 albums, and 610 of these also appeared among the RIAA certified albums. I merged these data and coded the Zagatincluded albums as critically acclaimed (albeit by amateur critics). This is a slightly peculiar data set: it includes all albums selling 0.5 million copies or more (up to 2004), as well as almost 400 critically acclaimed albums that were not certified and therefore (we can infer) sold fewer than 0.5 million copies. What the dataset is missing, of course, is the vast lot of albums that never reach "gold."

A regression of log sales on a Zagat-rated indicator shows that rated albums sell roughly double the number of units, among the sample of largely RIAA certified albums. See Table 3, column (1). Columns 2 and 5 add year dummies, with similar results. Finally, column 3 adds 
artist fixed effects. In this specification, the effect of certification is identified from the sales difference between an artist's rated and unrated albums. The effect size increases in size and significance: albums that are critically acclaimed sell more than twice as many copies. This relationship provides additional evidence that the number of critically acclaimed albums produced in a year is relevant to demand and therefore to consumer and producer surplus.

\section{Results}

\section{Empirical Strategy}

We would like to measure the impact of the various post-Napster changes in music demand and supply on the quantity of new music coming to market Ideally, we would have data on both an "experiment" and a "control." Here, we observe the experiment - the world that experienced the decade since Napster - but we have no obvious control. We can nevertheless make a few comparisons that are suggestive of the effect on supply since Napster. First, we can compare the post-Napster period with the dawn of the Napster era (1999), simply asking whether supply has contracted. This is of course imperfect as a way to measure Napster's effect because - as we have seen above - music supply exhibits trends even in the absence of shocks to appropriability (e.g. the peaks in creative output in the 1960s and 1990s). Second, if we think the pre-Napster trend in the flow of new works would have continued, then we can measure a possible contraction relative to a trend defined by the pre-Napster supply index. Third, we can use the the flow of critically acclaimed new songs - rather than albums - as a control and ask 
whether the flow of consequential new albums shrinks relative to the flow of new songs, particularly following the iTunes Music Store's revitalization of the single in 2003.

Even if we cannot know the supply that would have been available absent Napster, we can assess the most dire predictions concerning whether music supply has dwindled. That is, we can ask how the recent decade compares with the previous four decades.

\section{Does the Volume of High Quality Music Decline Post-Napster?}

Of our 64 album indices, 58 extend at least a few years into the post-Napster period. A glance at the various album indices gives little definitive indication of whether supply declines following Napster. Some appear to rise while others appear to fall. If each of the indices contains noise along with signal, we can get more information out of the indices by averaging them. However, indices vary substantially in the number of works included and, as a result, in their year-to-year variability as well. For example, the Paste Magazine list includes 50 albums for the 2000-09 decade, while the Pitchfork Media list includes 200 albums for the same period and our Metacritic data include over 4000 albums for roughly the same period. Because indices based on more underlying works should provide more accurate descriptions of each year's output, we weight indices in all what follows (we also report unweighted indices for comparison). Specifically, we weight by the number of works included in an index, divided by the number of years the index covers. Hence, the weight for Pitchfork's top 200 albums of the 2000s decade is 20, while the weight for SPIN's top 125 albums of the 25 -years between 1985 and 2010 is 5 . 
We can measure the change in annual new works following Napster via the following weighted regression:

$\ln \left(y_{i t}\right)=\mu_{i}+\alpha t+\epsilon_{i t}$, where $y_{i t}$ is album supply index $i$ in time $t$ (e.g. the number of albums from 2003 on Pitchfork's list of the top 200 albums of the 2000s), $t$ is a time trend, and $\mu_{i}$ is an index-specific fixed effect, and the model is estimated for years following Napster. In this model $\alpha$ shows the annual percent change in supply indices. As Table 4 shows, the weighted album and song indices exhibit no statistically discernible trends following Napster. Based on the post1999 trends, there is little evidence that the supply of new works has increased or contracted since Napster.

While the post-Napster trend is interesting, it does not provide an estimate of the effect of Napster, except under the restrictive assumption that the supply would have remained constant at its 1999 level in the absence of Napster. A comparison of pre- and post-Napster supply indices has greater promise for revealing the effect of Napster on supply. While none of our individual indices of supply cover the entire period since 1960 (or even 1980), the series collectively cover the period back to 1960. If we could "splice" the series together, then we could construct a continuous index covering both a long period prior to Napster and the decade following Napster. Figure 5 shows the time periods covered by the 88 different indices. ${ }^{20}$ Importantly, all consecutive years are covered by at least one series. For example, 78 series begin in 2000 , but nine series cover both 1999 and 2000, effectively allowing us to construct a continuous series over the interval 1999-2000. All two-year intervals since 1960 are similarly covered.

\footnotetext{
${ }^{20}$ The lines in Figure 5 cover only the years we do not exclude for reasons discussed in the data section.
} 
We can describe the time pattern of new works supply with a regression with index dummies and flexible time dummies: $\ln \left(y_{i t}\right)=\mu_{i}+\theta_{t}+\epsilon_{i t}$, where $\theta_{t}$ is a time effect common across indices for year $t$ (and other variables are defined as above). We estimate this model using the weights described above. Figure 6 shows time series plots of the annual values of $\theta_{t}$, along with a vertical line in 1999. Dotted lines define the 95 percent confidence intervals. Figure 7 repeats the exercise for songs. Because the regression dependent variable is in logs, the index is in percent terms.

All of the indices exhibit some decline following Napster. But all of the indices were also falling fairly steadily in the half decade prior to Napster. This suggests a second approach to measuring the effect of Napster, using the pre-Napster period to identify the trend in supply. That is, we can estimate the equation $\ln \left(y_{i t}\right)=\mu_{i}+\beta t+\alpha t \delta_{t}^{\text {post }}+\epsilon_{i t}$, where $\delta_{t}^{\text {post }}$ is a dummy that is 1 for the period following 1999 and 0 before. The coefficient $\beta$ shows the time trend pre-Napster, and $\alpha$ measures the annual divergence in the supply growth rate following Napster. The key question in implementing this approach is how much pre-Napster data to include for identifying $\beta$ (and therefore $\alpha$ ). It is clear from Figure 6 that album supply was falling prior to Napster. If we begin the estimation with data from the mid-1990s, we will impose the assumption that music supply would have continued to decline following Napster. This will, in turn, cause $\alpha$ to be positive, suggesting that music supply growth has diverged upward from its pre-Napster trend.

Of course, as we include more years of pre-Napster data, we can generate very different values for $\alpha$. Table 5 shows the different estimates obtained with different pre-Napster periods. For example, when the pre-Napster period begins in 1995, the growth rate in supply increases 
relative to the pre-existing trend; and this difference is statistically significant, and it swamps the pre-Napster rate of decline. This pattern holds for the other estimation starting dates, except for 1980. When we begin the pre-Napster period in 1980, both the pre-Napster trend and the postNapster divergence are statistically insignificant. Thus, this approach provides no indication that supply patterns have changed, relative to pre-existing trends, since Napster.

A third approach is to find a suitable control for the quantity of new albums. A potentially promising avenue is the comparison between songs and albums. While the returns to producing all recorded music fell after 1999, the appearance - and rapid rise - of the iTunes Music Store in 2003 re-established individual songs ("singles") as highly marketable works. For example, in 1999 sales of singles stood at 62.5 million units, accounting for only 2 percent of US recorded music sales. In 2009, by contrast, singles sales stood at $\$ 1.14$ billion, or almost 15 percent of US recorded music sales. ${ }^{21}$ Thus, while the rewards from producing albums appear to have fallen since 1999, the rewards from producing singles appear to have risen since 2003 . If this is so, then we can compare the time pattern of creative supply of albums and singles to identify a copyright-induced effect on album supply relative to single supply. The evident date for the "experiment" is the 2003 appearance of the iTunes Music Store.

Figure 8 shows our index of album supply juxtaposed with our index of singles supply since 1980, based on separate album and song year effects from weighted regressions. At face, they look rather similar. We can test for an album supply effect (relative to the single) using the following model:

\footnotetext{
${ }^{21}$ See RIAA's 2003 Yearend Statistics and the RIAA's 2008-09 shipment statistics at http://www.riaa.com/keystatistics.php? content_selector=2008-2009-U.S-Shipment-Numbers, accessed October 26, 2010.
} 


$$
\ln \left(y_{i t}\right)=\mu_{i}+\theta_{t}+\pi_{1} \delta_{i}^{\text {Napster }}+\pi_{2} \delta_{i}^{i \text { Tunes }}+\epsilon_{i t}
$$

where $\delta_{i}^{\text {Napster }}$ and $\delta_{i}^{i \text { Tunes }}$ are indicators that are zero until 1999 and 2003, respectively, and one thereafter. Table 6 reports results, and none of the coefficients on the indicators are statistically significant. Thus, this approach, like the others we have explored, provides no evidence of an effect of changed appropriability of albums, relative to songs, on the quantity of consequential new albums.

\section{New Artists vs New Music}

The evidence thus far indicates no decline in the volume of new recorded music products forthcoming since Napster. It is possible, however, that the new music is coming from artists who were established prior to Napster. While products still come to market, it is possible that new artists are not establishing careers.

To explore this we examined the albums on three analogous best-of lists, for the $1980 \mathrm{~s}$, the 1990s, and the 2000s, from Pitchfork Media. For each of the 300 albums, we determined the year the artist released his, her, or their first recording (whether an album, a single, or an "EP"). ${ }^{22}$ These data allow us to calculate the career age of an artist at the time he has an album on a bestof list. The question is whether artists have continued to establish careers since 1999. To explore this, we calculate the share of best albums since 1999 whose artists' first recordings appeared after 1999. Since 1999, 49 percent of artists on the best of the 2000s list debuted following Napster. Figure 9 shows this year-by-year pattern: there is a systematic, although not a monotonic, rise from 10 percent of albums in 2000 to 100 percent at the end of the decade. On

\footnotetext{
${ }^{22} \mathrm{We}$ obtained the discography information from http://www.discogs.com, accessed January 1, 2011.
} 
average, about half of the best-of albums since Napster are from artists whose recording debut occurred since Napster.

Although this is clearly a substantial share, determining whether the launching of new artists has changed requires a comparison with earlier periods. To this end, we calculate analogous annual shares for the two previous decades, the annual share of 1980s best-of albums from artists debuting after 1979, and the share of 1990s best-of albums from artists debuting after 1989. All three patterns are very similar, rising fairly steadily to 100 percent by the end of each decade. A regression of a dummy for whether an artist debuted since the beginning of the decade of his appearance on dummies for years since the beginning of the decade and a dummy for the post-Napster decade confirms the lack a statistically meaningful difference in the tendency for new artists to appear on the list since Napster.

\section{Discussion and Conclusion}

How do we reconcile the demand reduction wrought by piracy since Napster with the continued creation of new recorded music documented above? One possibility is that the supply curve is vertical, i.e. that creative activity is invariant to reward. While new music itself might be created without regard for reward, the mundane aspects of bringing it to market - production, promotion, and distribution - are generally undertaken by profit-seeking private firms, and they have costs which must be covered to keep new products coming forth. These are presumably the costs that concern IFPI and RIAA members. The intuitive reasonableness of an upward-sloping supply curve for new products suggests a different reconciliation of reduced demand with 
continued "output," that new technologies have reduced costs, shifting supply out as demand has contracted. Bringing music successfully to market has three component activities - creation, promotion, and distribution - and new technologies have changed each of these substantially.

Creation includes both solitary artistic activity as well as recording, mixing, engineering, and manufacturing salable recorded music products. Many aspect of creation were traditionally expensive, but a succession of new technologies has reduced costs. Caves (2000) points out that the development of low-cost tape recording equipment after World War II "promoted the entry of more than a thousand new record labels between 1948 and 1954."23 Kalmar (2002) notes that with the development of digital audio tape in 1987, "a label can set up their own recording studio for about five grand." ${ }^{24}$ The cost reductions have accelerated since Napster: Software such as Pro Tools turns an inexpensive personal computer into a home recording studio. A starter version of the software sells for about $\$ 100 .^{25}$

Music is an experience good, and consumers need to become aware of music to be interested in purchasing it. Record companies have traditionally made consumers aware of their products by promoting their new releases on radio. Even prior to the Internet, the labels produced more music than radio stations could air, so the labels paid the stations to promote their music. While the literal practice of "payola" was outlawed in 1960, labels continued to pay for airplay through independent promoters, "men (large and accompanied by bodyguards) who were willing and able to gain control of radio stations' playlists." These payments were substantial: in

\footnotetext{
${ }^{23}$ See Caves (2000), pp. 157-8.

${ }^{24}$ See Kalmar (2002), p. 73.

${ }^{25}$ See Donald Bell, “Avid Introduces new Pro Tools Studio Bundles.” CNET, Oct 1, 2010 (http://news.cnet.com/8301-17938 105-20018292-1.html, accessed October 28, 2010).
} 
1985 the record labels collectively paid \$65 million for airplay when the industry's pre-tax profit was $\$ 200$ million. The cost of promoting a hit single was about $\$ 150,000 .^{26}$

Since Napster, the process of musical discover has changed substantially. While radio listening is in decline, consumers now learn about new music from a variety of web sources, including Pandora, MySpace, and YouTube. According to the 2010 "Infinite Dial” study conducted by Edison Research and Arbitron, the Internet was by far the most popular medium that consumers age 12-34 used first to learn about new music. Over half (52 percent) turned first to the Internet, followed by 32 percent using radio. Just over a quarter ( 27 percent) of the population 12 and over had used Internet radio in the previous month, and Pandora was the most recognized name: among those who had ever listened to Internet radio, 28 percent named Pandora, followed by Yahoo Music (9 percent), AOL Radio (6), and Last.fm (4). ${ }^{27}$ As the Infinite Dial name suggests, the Internet has undermined the scarcity of terrestrial radio stations as music promotion channels.

Distribution, too, has been changed substantially by the Internet. Caves (2000) emphasizes a number of factors favoring large scale enterprises in physical distribution during the physical era, including a need to get a large quantity of physical product into many stores before popularity wanes. Of course, it is now possible to distribute musically electronically, eliminating inventory issues. Using TuneCore's service, for example, an artist can make his

\footnotetext{
${ }^{26}$ Caves (2000), p. 292, provides the source for the quote and the data cited in this paragraph.

${ }^{27}$ See "The Infinite Dial 2010: Digital Platforms and the Future of Radio." (http://www.fmqb.com/goout.asp?u=http://www.edisonresearch.com/home/archives/2010/09/the american_youth_s tudy 2010 part one radios future.php accessed October 28,2010 ).
} 
song available on iTunes for $\$ 9.99 .^{28}$ Clearly, the various costs of bringing music to market

have come down substantially since Napster.

In his critical account of the music industry's response to digital transformation, Steven

Knopper (2009) argues out that these changes largely obviate the roles of the major record

labels:

[Prior to Napster, an] "artist who wanted to make a record needed studio time - and that cost money, which meant a sizable loan from a label. An artist who wanted to get a single onto a radio playlist needed connections - and that usually meant a label executive who had the money to hire an independent promoter. An artist who wanted to sell millions of copies of a record needed a big-time distributor with the clout to push CDs into big stores like Best Buy or Target - and that meant one of the label's own subsidiaries, like WEA or CEMA. Today, it's not necessary to hook up with a label to do all these things. An artist can make a record cheaply, and professionally, using software like Pro Tools. An artist can forgo the radio, building buzz and exposure online via do-it-yourself websites like MySpace, viral videos on YouTube, or any number of social networking services from Facebook to Garageband.com. As for distribution, who needs crates, trucks, warehouses, stores, or even the discs themselves?"29

Leeds (2005) makes the similar point that independent labels appear to have lower costs, allowing them to subsist on smaller sales:

"Unlike the majors, independent labels typically do not allocate money to producing slick videos or marketing songs to radio stations. An established independent like Matador Records - home to acts including Pretty Girls Make Graves and Belle and Sebastian - can turn a profit after selling roughly 25,000 copies of an album; success on a major label release sometimes doesn't kick in until sales of half a million."

Changes in the cost structure of operating a record label are consistent with Handke's (2006)

observation that the number of German record labels expanded following the advent of file sharing.

Do the data support the contention that independent labels are bringing forth more of the supply following Napster? Pitchfork Media's ranking of the top albums of the 1980s, 1990s, and

\footnotetext{
${ }^{28}$ See http://www.tunecore.com/, accessed October 28, 2010. At the site: "What Does Worldwide Distribution Cost” $\$ 9.99$ per single, $\$ 9.99$ per ringtone, $\$ 49.99$ per album."

${ }^{29}$ See Knopper (2009), p. 246.
} 
the 2000s includes each album's issuing label or, more commonly, a less recognized entity that may be either an independent label or a sub-label of one of the majors. Using mostly Wikipedia entries, I have been able to code each of the labels on the top 100 albums of each decade as either a major or an independent. This is not a trivial task, as the major owners produce records under a long list of label imprints.

The data provide support for the idea that independent labels are playing an increasing role (see Figure 10). While the share of the top 100 on independent labels was 50 percent in both the 1980 s and the $1990 \mathrm{~s}$, it rose to 60 percent in the period since $1999 .^{30}$ This difference (between the 2000s and the previous two decades) is significant at the 5 percent level in a onesided test $(\mathrm{p}$-val $=0.04)$. The ascendance of independent labels has been noted elsewhere. Leeds (2005) writes of the independent labels' success in the face of the majors' difficult times: "Even as the recording industry staggers through another year of declining sales over all, there are new
signs that a democratization of music made possible by the Internet is shifting the industry's balance of
power. ... But no factor is more significant than the Internet, which has shaken up industry sales patterns
and, perhaps more important, upended the traditional hierarchy of outlets that can promote music. Buzz
about an underground act can spread like a virus, allowing a band to capture national acclaim before it even
has a recording contract, as was the case this year with Clap Your Hands Say Yeah, an indie rock band." The heightened role of independent labels suggests a simple reconciliation of the continued supply of music despite financial distress at major labels: it appears that entities other than the major labels are bringing forth a higher share of music in the period since Napster.

The new era may not stem the supply of music, but it may change the industrial organization of the music industry. It appears that majors have traditionally cross subsidized their exploratory activity - investing in new artists - with exploitative activities, selling

\footnotetext{
${ }^{30}$ Pitchfork's focus on artists they view as interesting likely explains the high share of independent label releases among their most highly rated albums. According to Leeds (2005), independent labels' collective share of recorded music revenue rose to 18 percent (27 percent including indie albums distributed by majors) in 2005, its highest share in 5 years.
} 
predictably successful albums by already-popular artists. The independents appear able to participate in exploratory activities without needing to find artists who will generate sufficient revenue for cross-subsidization. And while major labels facing financial distress may be able to invest less in new artists, it is also possible that these artists' music can nevertheless find its way to market via the less costly distribution channel that independent labels provide.

This still begs the question of why artists themselves would continue to produce works in the face of the smaller payoffs promised even by a successful independent label release. Many observers point to heightened roles of complements to recorded music in artists income. Connolly and Krueger (2006) and Mortimer, Nosko, and Sorenson (2010) document that concert revenue has increased since Napster, and Shapiro and Varian (1999) emphasized the possible stimulating effect of widely available - and difficult-to-protect - recorded music on the sale of other complements such as t-shirts.

File sharing has presented a great challenge to the recording industry. It is clear to most observers that file sharing has undermined the effective copyright protection afforded to recorded music. In spite of this, the supply of recorded music appears not to have fallen off much since Napster, and there is at least suggestive evidence that independent music labels, which operate with lower breakeven thresholds, are playing an increased role in bringing new works to market.

This is a relatively difficult topic to study, so more than the usual number of caveats is in order. We lack a compelling counterfactual for the post-Napter musical world, so it is hard to measure Napster's effect on new music with great confidence. It is possible that, absent the demand contraction, the cost reductions would have ushered in a substantial increase in new high-quality works. Second, even if it is true that music supply remains forthcoming in the face 
of weakened effective copyright protection, it is not clear what relevance these results have for other media that differ in their creative processes. While new recording and distribution technologies have put the means to make and distribute music in the reach of many more people, it remains substantially more costly to create other types of works, such as movies. Even if one takes the suggestive results of this study to mean that new music has continued to flow despite weaker copyright protection, we have no evidence that these lessons carry over to other media. It is often said - and is as true as ever in this context - that more research is needed. 


\section{References}

Blackburn, David. “On-line Piracy and Recorded Music Sales.” Unpublished Manuscript, Harvard University, December 2004.

Blashil, Pat (coordintator for Zagat Survey). Music Guide: 1000 Top Albums of All Time. 2003. New York: Zagat Survey.

Boldrin, Michele and David K. Levine. Against Intellectual Monopoly. Cambridge University Press. 2008.

Caves, Richard E. Creative Industries: Contracts between Art and Commerce. Harvard University Press: Cambridge, MA. 2000.

Connolly, Marie \& Krueger, Alan B., 2006. "Rockonomics: The Economics of Popular Music," Handbook of the Economics of Art and Culture, Elsevier.

Handke, Christian. "Plain Destruction or Creative Destruction? Copyright Erosion and the Evolution of the Record Industry." Review of Economic Research on Copyright Issues, 2006, vol 3(2): 29-51.

Handke, Christian, "Digital Copying and the Supply of Sound Recordings." Unpublished Manuscript, 2010, available at http://www.acei2010.com/upload/acei/handke.pdf .

Kalmar, Veronika. Label Launch: A Guide to Record Recording, Promotion, and Distribution. St. Martin's Griffin: New York. 2002.

Knopper, Steve . Appetite for Self-Destruction: The Spectacular Crash of the Record Industry in the Digital Age. Free Press: New York. 2009.

Larkin, Colin. “A Brief History of Pop Music.” In The Encyclopedia of Popular Music, $5^{\text {th }}$ edition, edited by Colin Larkin, Omnibus Press/MUZE: London and New York. 2007.

Leeds, Jeff. “The Net is a Boon for Indie Labels.” New York Times. December 27, 2005.

Levy, Joe and Editors of Rolling Stone, The 500 Greatest Albums of All Times. Wenner Publishing. November 16, 2005

Liebowitz, Stan J. "File Sharing: Creative Destruction or Just Plain Destruction?"

Journal of Law and Economics, vol. 49, no. 1, April 2006, pp. 1-28.

Oberholzer-Gee, Felix and Koleman Strumpf. "The Effect of File Sharing on Record Sales: An Empirical Analysis.” Journal of Political Economy. Volume 115, Issue 1, Page 1-42, Feb 2007

Oberholzer-Gee, Felix and Koleman Strumpf. File-Sharing and Copyright. NBER's Innovation Policy and the Economy series, volume 10. ed. Joshua Lerner and Scott Stern. MIT Press. 2009. 
Mortimer, Julie Holland, Chris Nosko, and Alan Sorenson. "Supply Responses to Digital Distribution: Recorded Music and Live Performances." NBER Working Paper No. 16507. October 2010.

Rob, Rafael and Joel Waldfogel. "Piracy on the High C's: Music Downloading, Sales Displacement, and Social Welfare in a Sample of College Students." Journal of Law \& Economics. Volume 49, Issue 1, Page 29-62, Apr 2006.

Rob, Rafael and Joel Waldfogel. "Piracy on the High C's: Music Downloading, Sales Displacement, and Social Welfare in a Sample of College Students." NBER Working Paper 10874, October 2004.

Shapiro, Carl and Hal Varian. Information Rules. Harvard Business School Press. Cambridge, MA. 1999.

Zentner, Alejandro, "Measuring the Effect of File Sharing on Music Purchases." The Journal of Law and Economics. Volume 49, Issue 1, Page 63-90, Apr 2006. 
Figure 1

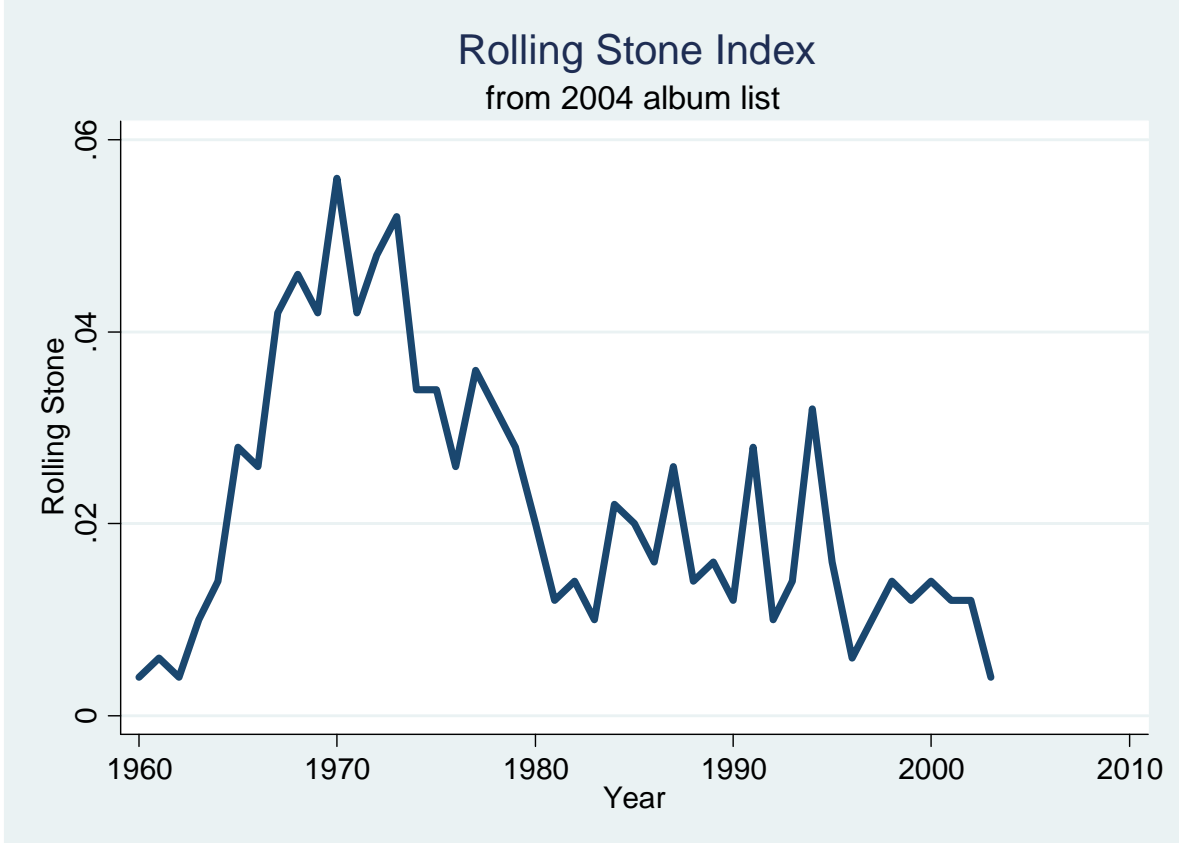

Figure 2

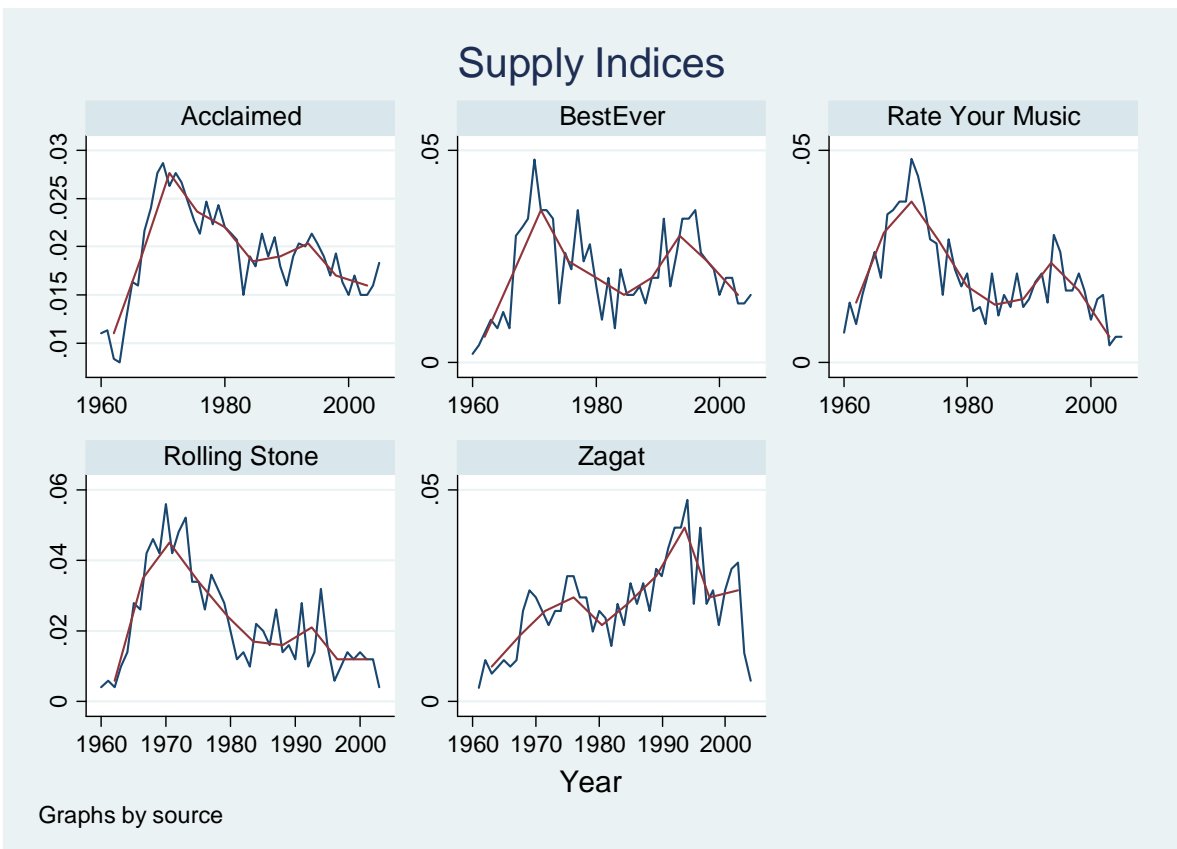


Figure 3

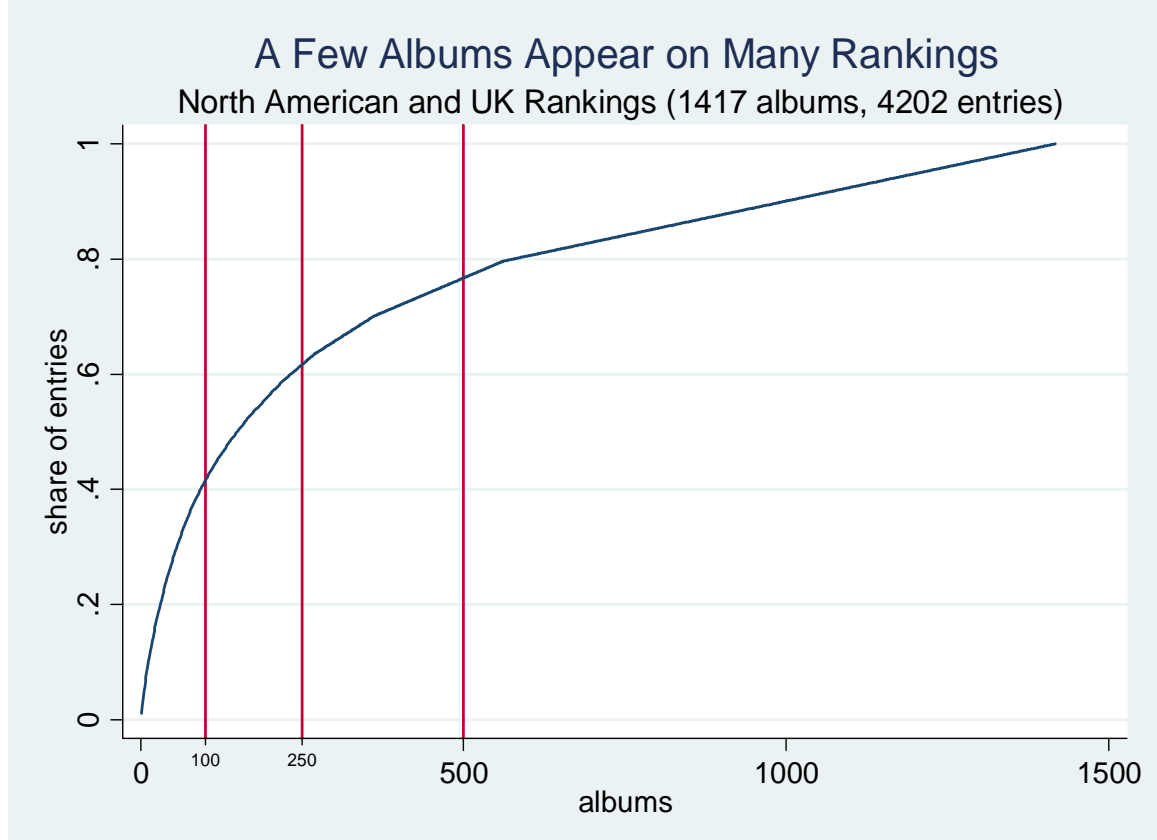

Figure 4

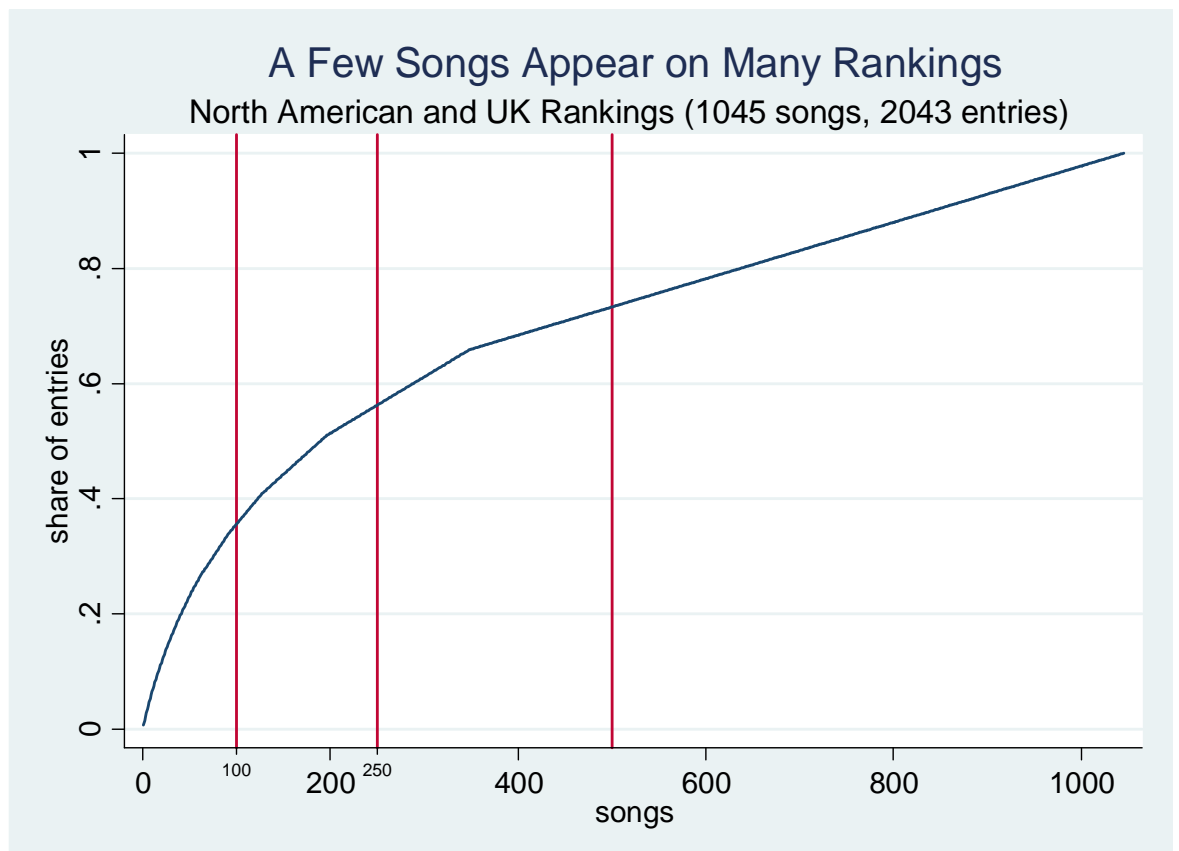


Figure 5

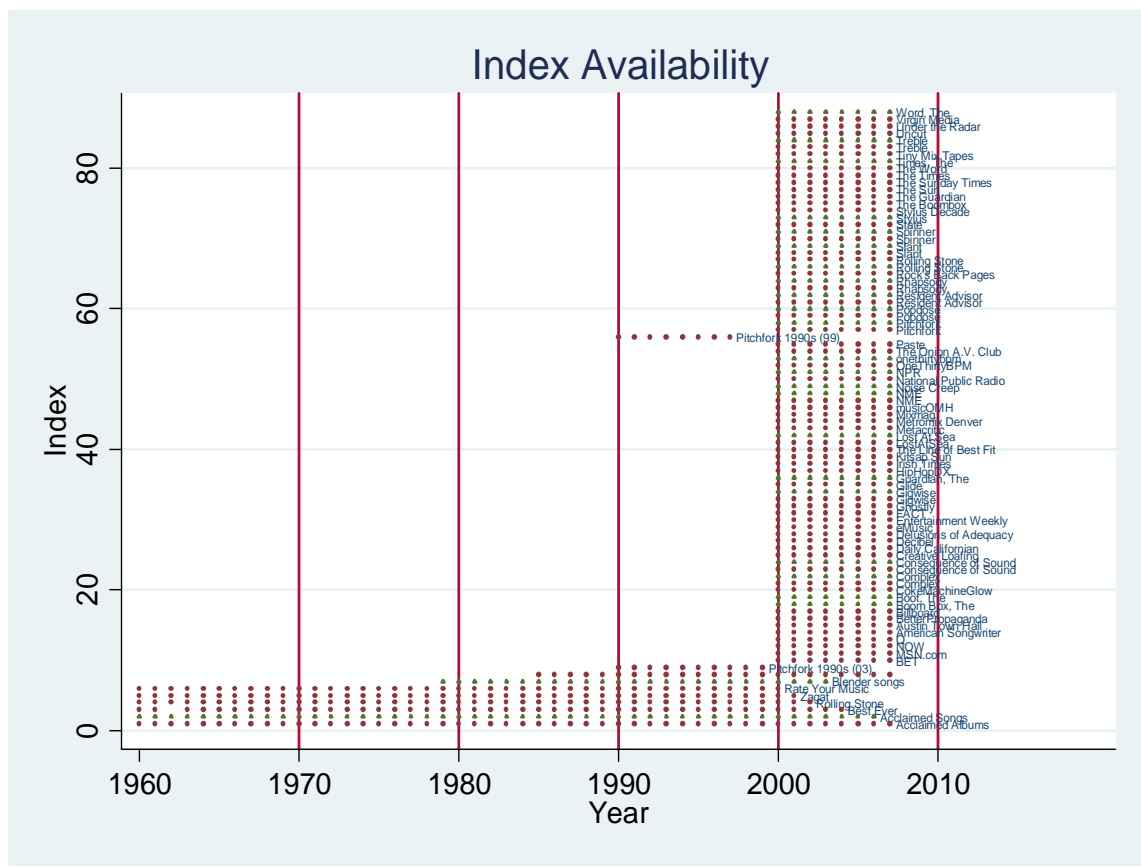

Figure 6

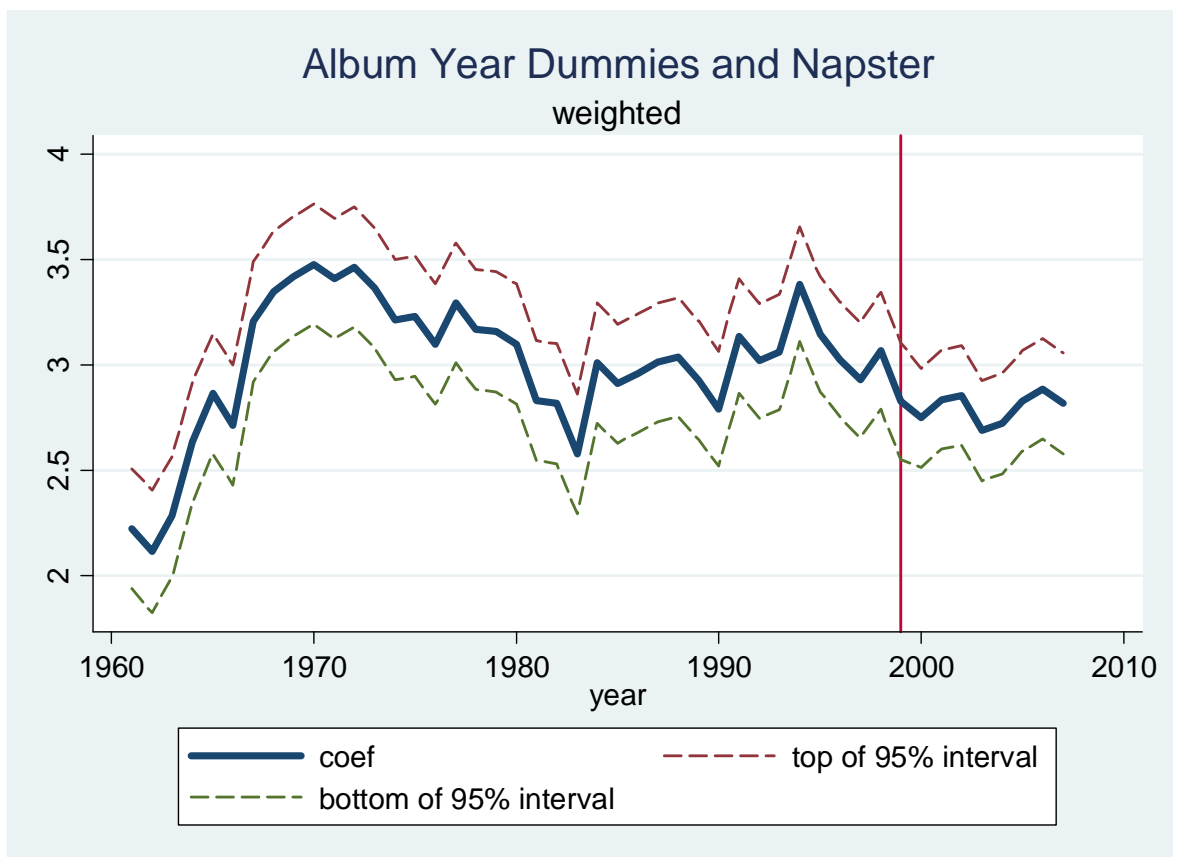


Figure 7

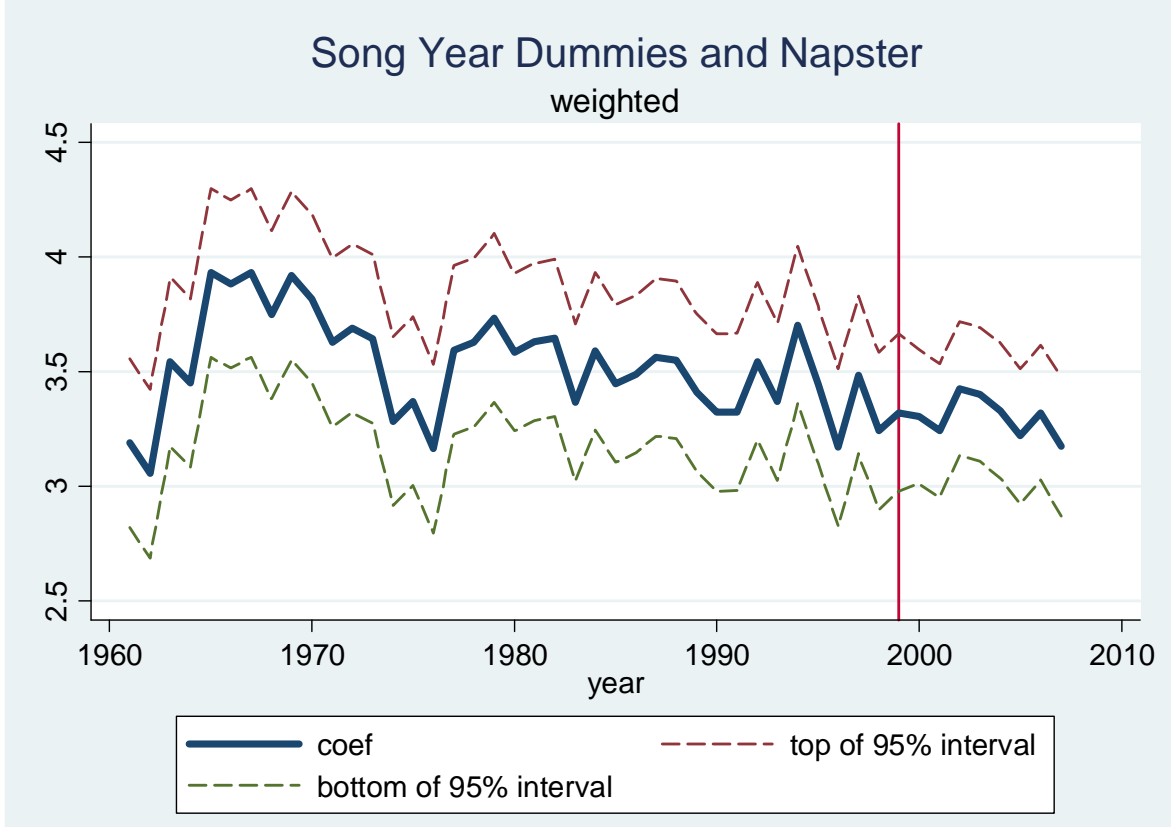

Figure 8

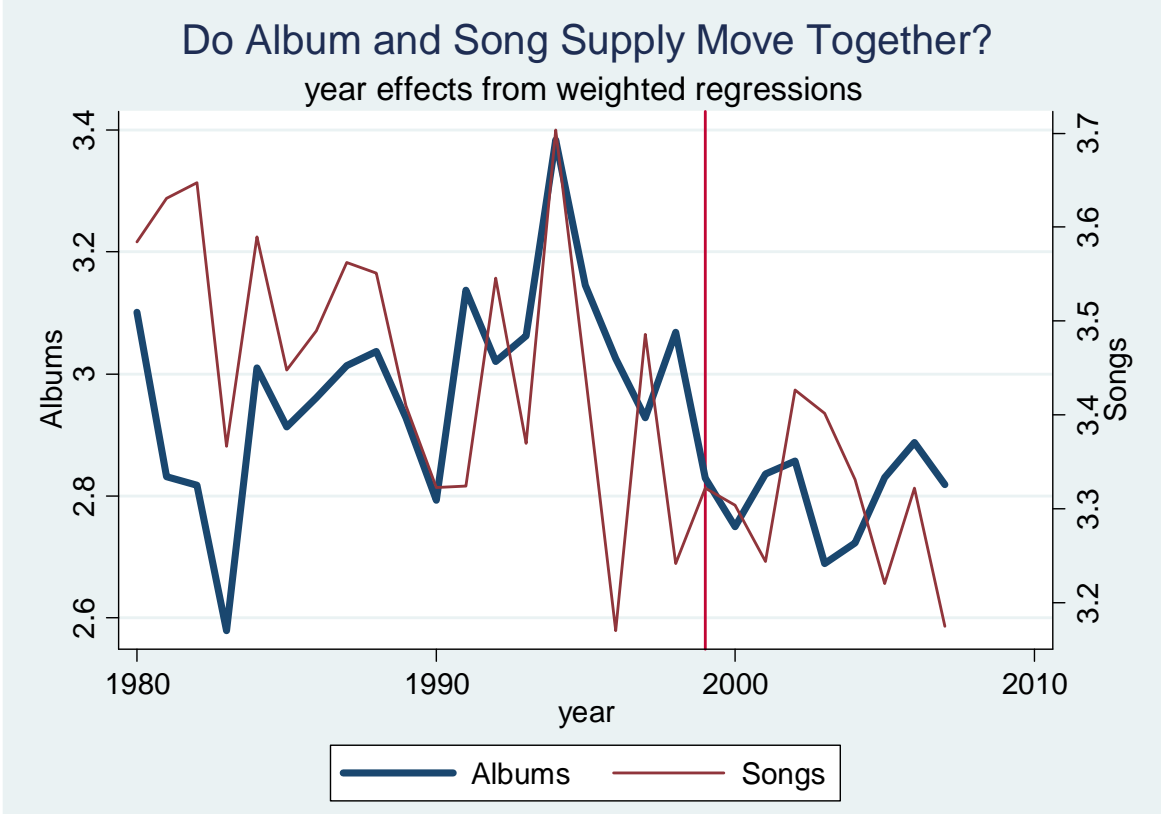


Figure 9

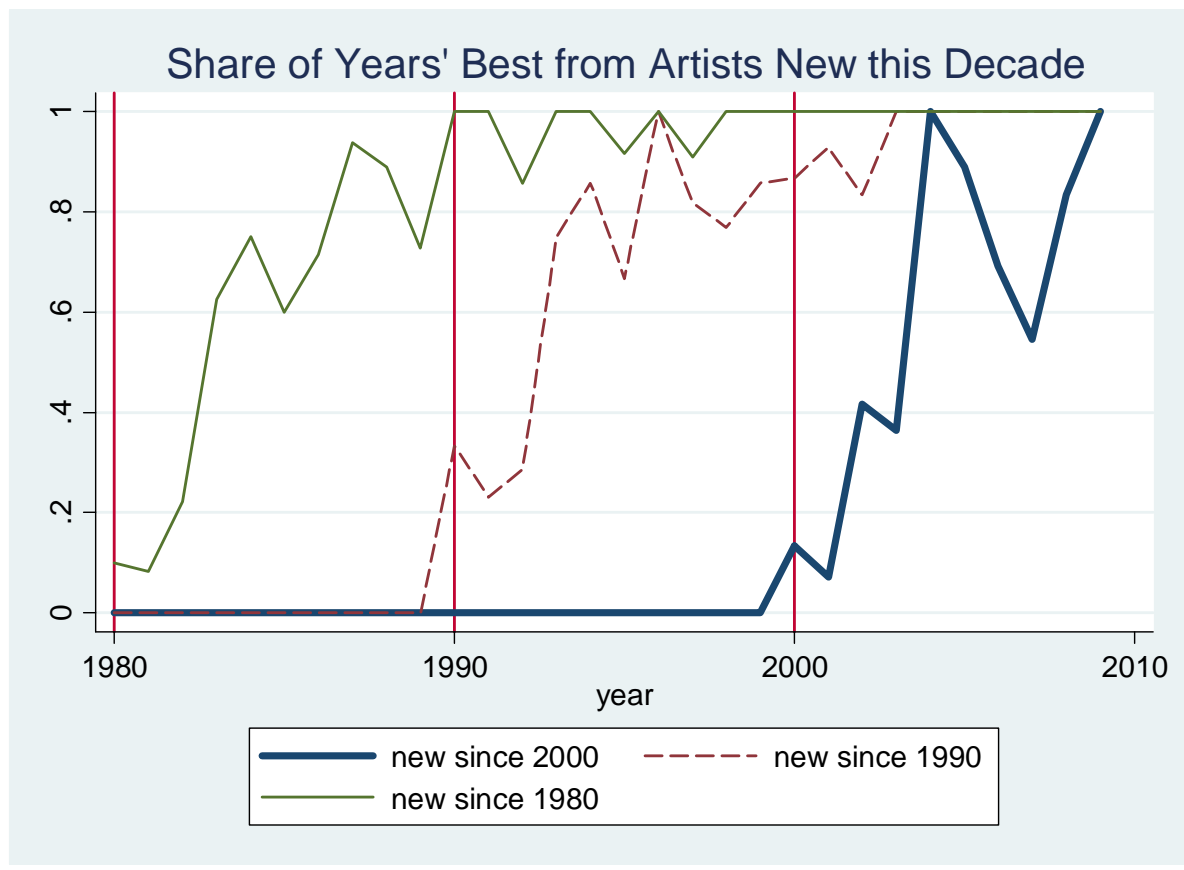

Figure 10

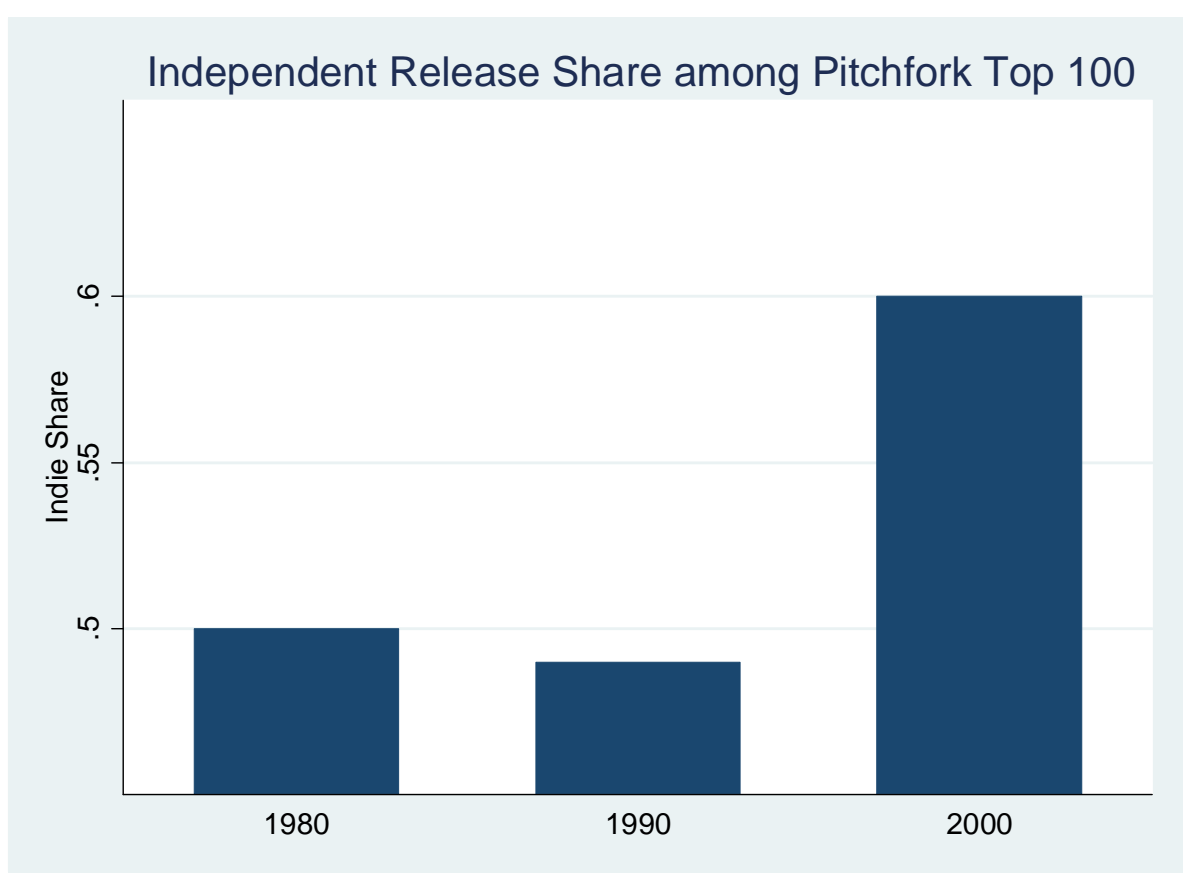


Table 1: The Most Listed Albums of the 2000s

\begin{tabular}{|c|c|c|c|c|c|}
\hline rank & artist & album & year & $\begin{array}{l}\text { Number } \\
\text { of lists }\end{array}$ & $\begin{array}{l}\text { RIAA } \\
\text { Certs }\end{array}$ \\
\hline 1 & Arcade Fire & Funeral & 2004 & 47 & \\
\hline 2 & Radiohead & Kid A & 2000 & 47 & $\mathrm{P}$ \\
\hline 3 & Strokes, The & Is This It & 2001 & 45 & G \\
\hline 4 & OutKast & Stankonia & 2000 & 37 & $3 \times P$ \\
\hline 5 & Wilco & Yankee Hotel Foxtrot & 2002 & 36 & G \\
\hline 6 & LCD Soundsystem & Sound of Silver & 2007 & 34 & \\
\hline 7 & Jay-Z & The Blueprint & 2001 & 34 & $2 \mathrm{xP}$ \\
\hline 8 & Radiohead & In Rainbows & 2007 & 30 & G \\
\hline 9 & Flaming Lips, The & Yoshimi Battles the Pink Robots & 2002 & 29 & G \\
\hline 10 & White Stripes, The & Elephant & 2003 & 29 & $\mathrm{P}$ \\
\hline 11 & Bon Iver & For Emma, Forever Ago & 2007 & 28 & \\
\hline 12 & Stevens, Sufjan & Illinois & 2005 & 28 & \\
\hline 13 & Arctic Monkeys & $\begin{array}{l}\text { Whatever People Say I Am, That's } \\
\text { What I'm Not }\end{array}$ & 2006 & 27 & \\
\hline 14 & Daft Punk & Discovery & 2001 & 27 & G \\
\hline 15 & West, Kanye & The College Dropout & 2004 & 26 & $2 \times P$ \\
\hline 16 & Winehouse, Amy & Back to Black & 2006 & 26 & $2 \times P$ \\
\hline 17 & Harvey, PJ & $\begin{array}{l}\text { Stories from the City, Stories from the } \\
\text { Sea }\end{array}$ & 2000 & 26 & \\
\hline 18 & Interpol & Turn On the Bright Lights & 2002 & 25 & \\
\hline 19 & White Stripes, The & White Blood Cells & 2001 & 24 & G \\
\hline 20 & Eminem & The Marshall Mathers LP & 2000 & 23 & $9 \mathrm{xP}$ \\
\hline 21 & Knife, The & Silent Shout & 2006 & 23 & \\
\hline 22 & Animal Collective & Merriweather Post Pavillon & 2009 & 22 & \\
\hline 23 & M.I.A. & Kala & 2007 & 22 & G \\
\hline 24 & Björk & Vespertine & 2001 & 21 & \\
\hline 25 & TV on the Radio & Return to Cookie Mountain & 2006 & 21 & \\
\hline 26 & Beck & Sea Change & 2002 & 20 & G \\
\hline 27 & Broken Social Scene & You Forgot It in People & 2002 & 20 & \\
\hline 28 & Modest Mouse & The Moon \& Antarctica & 2000 & 20 & G \\
\hline 29 & Streets, The & Original Pirate Material & 2002 & 20 & \\
\hline 30 & Fleet Foxes & Fleet Foxes & 2008 & 20 & \\
\hline 31 & Dylan, Bob & Love and Theft & 2001 & 19 & G \\
\hline 32 & Burial & Untrue & 2007 & 19 & \\
\hline 33 & Newsom, Joanna & Ys & 2006 & 19 & \\
\hline 34 & Yeah Yeah Yeahs & Fever to Tell & 2003 & 19 & G \\
\hline 35 & Dizzee Rascal & Boy in da Corner & 2003 & 19 & \\
\hline 36 & Antony and The Johnsons & I Am a Bird Now & 2005 & 18 & \\
\hline 37 & Vampire Weekend & Vampire Weekend & 2008 & 18 & G \\
\hline
\end{tabular}




\begin{tabular}{llllll}
38 & Adams, Ryan & Heartbreaker & 2000 & 18 & \\
39 & M.I.A. & Arular & 2005 & 17 & \\
40 & Panda Bear & Person Pitch & 2007 & 17 & \\
41 & OutKast & Speakerboxxx/The Love Below & 2003 & 17 & 11 XP \\
42 & Queens of the Stone Age & Songs for the Deaf & 2002 & 16 & G \\
43 & Jay-Z & The Black Album & 2003 & 16 & \\
44 & National, The & Boxer & 2007 & 16 & \\
45 & Bright Eyes & I'm Wide Awake It's Morning & 2005 & 16 & \\
46 & Madvillain & Madvillainy & 2004 & 16 & \\
47 & West, Kanye & Late Registration & 2005 & 15 & $3 x P$ \\
48 & At the Drive-In & Relationship of Command & 2000 & 15 & \\
49 & Ghostface Killah & Supreme Clientele & 2000 & 15 & $\mathrm{G}$ \\
50 & Postal Service, The & Give Up & 2003 & 15 & $\mathrm{G}$ \\
\hline
\end{tabular}

Based on 56 "best of the 2000s" album lists from North America and the UK. 
Table 2: The Most Listed Songs of the 2000s

\begin{tabular}{|c|c|c|c|c|}
\hline rank & artist & song & year & $\begin{array}{c}\text { On how } \\
\text { many of the } \\
22 \text { lists? }\end{array}$ \\
\hline 1 & M.I.A. & Paper Planes & 2007 & 15 \\
\hline 2 & Jay-Z & 99 Problems & 2003 & 14 \\
\hline 3 & Gnarls Barkley & Crazy & 2006 & 14 \\
\hline 4 & The White Stripes & Seven Nation Army & 2003 & 14 \\
\hline 5 & Beyoncé feat. Jay-Z & Crazy in Love & 2003 & 13 \\
\hline 6 & Yeah Yeah Yeahs & Maps & 2003 & 13 \\
\hline 7 & Franz Ferdinand & Take Me Out & 2004 & 13 \\
\hline 8 & OutKast & Hey Ya! & 2003 & 13 \\
\hline 9 & The Flaming Lips & Do You Realize?? & 2002 & 12 \\
\hline 10 & Missy Elliott & Get Ur Freak On & 2001 & 12 \\
\hline 11 & Daft Punk & One More Time & 2000 & 11 \\
\hline 12 & OutKast & B.O.B. (Bombs Over Baghdad) & 2000 & 11 \\
\hline 13 & Kylie Minogue & Can't Get You Out of My Head & 2001 & 11 \\
\hline 14 & Rihanna feat. Jay-Z & Umbrella & 2007 & 10 \\
\hline 15 & Justin Timberlake & Cry Me a River & 2002 & 10 \\
\hline 16 & OutKast & Ms. Jackson & 2000 & 10 \\
\hline 17 & LCD Soundsystem & Losing My Edge & 2002 & 10 \\
\hline 18 & The Knife & Heartbeats & 2003 & 10 \\
\hline 19 & Radiohead & Idioteque & 2000 & 10 \\
\hline 20 & The Rapture & House of Jealous Lovers & 2002 & 10 \\
\hline 21 & R. Kelly & Ignition (Remix) & 2003 & 10 \\
\hline 22 & Kanye West & Jesus Walks & 2004 & 10 \\
\hline 23 & Amy Winehouse & Rehab & 2006 & 9 \\
\hline 24 & Modest Mouse & Float On & 2004 & 9 \\
\hline 25 & The Shins & New Slang & 2001 & 9 \\
\hline 26 & Britney Spears & Toxic & 2003 & 9 \\
\hline 27 & Eminem & Lose Yourself & 2002 & 9 \\
\hline 28 & The Strokes & Last Nite & 2001 & 8 \\
\hline 29 & Arcade Fire & Wake Up & 2004 & 8 \\
\hline 30 & Peter Bjorn and John & Young Folks & 2006 & 8 \\
\hline 31 & Queens of the Stone Age & No One Knows & 2002 & 8 \\
\hline 32 & MGMT & Kids & 2008 & 8 \\
\hline 33 & Hot Chip & Over and Over & 2006 & 8 \\
\hline 34 & The White Stripes & Fell in Love With a Girl & 2002 & 8 \\
\hline 35 & Jay-Z & Izzo (H.O.V.A.) & 2001 & 8 \\
\hline 36 & LCD Soundsystem & All My Friends & 2007 & 8 \\
\hline 37 & Kelly Clarkson & Since U Been Gone & 2004 & 8 \\
\hline
\end{tabular}




\begin{tabular}{lllll}
\hline 38 & Johnny Cash & Hurt & 2002 & 8 \\
39 & The Killers & Mr. Brightside & 2003 & 7 \\
40 & The Postal Service & Such Great Heights & 2003 & 7 \\
41 & Arcade Fire & Rebellion (Lies) & 2004 & 7 \\
42 & Animal Collective & My Girls & 2009 & 7 \\
43 & Radiohead & Pyramid Song & 2001 & 7 \\
44 & Eminem feat. Dido & Stan & 2000 & 7 \\
45 & Arctic Monkeys & I Bet You Look Good on the & 2005 & 7 \\
46 & The Walkmen & Dancefloor & 2004 & 7 \\
47 & TV on the Radio & The Rat & 2006 & 7 \\
48 & T.I. & Wolf Like Me & 2006 & 7 \\
49 & Lil Wayne & What You Know & 2008 & 7 \\
50 & The Strokes & A Milli & 2001 & 7 \\
\hline
\end{tabular}

Based on 22 North American and UK lists. 
Table 3: Zagat Ratings and Album Sales

\begin{tabular}{lccccc}
\hline & $(1)$ & $(2)$ & $(3)$ & $(4)$ & $(5)$ \\
\hline Zagat Rated & linear & linear & linear & interval & interval \\
& 1.084 & 1.224 & 2.146 & 1.078 & 1.227 \\
Year effects & $(0.064)^{* *}$ & $(0.066)^{* *}$ & $(0.082)^{* *}$ & $(0.066)^{* *}$ & $(0.068)^{* *}$ \\
Individual FE & No & yes & Yes & No & Yes \\
Observations & no & no & yes & no & no \\
R-squared & 8126 & 8126 & 8113 & & \\
\hline
\end{tabular}

Notes: Columns 1-3 report linear regressions. Uncertified albums are coded with 0 sales. The dependent variable for other observations are the RIAA certification level. Columns (4) and (5) report normal interval regressions.

Uncertified albums are assumed to sell between 0 and 0.5 million, Gold albums are assumed to sell between 0.5 and 1 million, and $\mathrm{N} x$ multiplatinum albums are assumed to have sold between $\mathrm{N}$ and $\mathrm{N}+1$ million copies. Standard errors in parentheses. $*$ significant at $5 \%$ level; ** significant at $1 \%$ level. 
Table 4: Time Trends in Music Supply Following Napster

\begin{tabular}{lcc}
\hline & (albums) & (songs) \\
\hline Year & 0.0071 & -0.0104 \\
& $(0.0063)$ & $(0.0089)$ \\
Constant & -14.0067 & 20.9655 \\
& $(12.5821)$ & $(17.8453)$ \\
Observations & 454 & 176 \\
R-squared & 0.88 & 0.93 \\
\hline
\end{tabular}

Note: weighted regression of log index values following 1999 on index dummies (source fixed effects) and a linear time trend (year). Standard errors in parentheses. ${ }^{*}$ significant at $5 \%$ level; ** significant at $1 \%$ level. 
Table 5: Napster Effect on Albums Relative to Pre-Napster Trend

\begin{tabular}{lcccc}
\hline & $(1)$ & $(2)$ & $(3)$ & $(4)$ \\
\hline Year & -0.0772 & -0.0238 & 0.0000 & -0.0144 \\
& $(0.0202)^{* *}$ & $(0.0076)^{* *}$ & $(0.0032)$ & $(0.0019)^{* *}$ \\
Post-1999 Divergence & 0.0835 & 0.0253 & -0.0056 & 0.0153 \\
& $(0.0225)^{* *}$ & $(0.0111)^{*}$ & $(0.0078)$ & $(0.0074)^{*}$ \\
Constant & 154.5180 & 47.7673 & 0.2677 & 29.0892 \\
& $(40.3130)^{* *}$ & $(15.2735)^{* *}$ & $(6.3026)$ & $(3.8581)^{* *}$ \\
Observations & 495 & 535 & 590 & 640 \\
R-squared & 0.89 & 0.89 & 0.90 & 0.90 \\
Pre-period start & 1995 & 1990 & 1980 & 1970 \\
\hline
\end{tabular}

Notes: Regressions of log album supply indices on a time trend ("year") and a divergent post-1999 trend. Regressions are weighted by the number of works included in each index, divided by the number of years it covers. Standard errors in parentheses. * significant at 5\% level; ** significant at $1 \%$ level 
Table 6: Album Supply following Napster and iTunes Relative to Songs

\begin{tabular}{lccc}
\hline & $(1)$ & $(2)$ & $(3)$ \\
\hline album x post-1999 & -0.0054 & & -0.0455 \\
& $(0.0771)$ & 0.1008 & $(0.0799)$ \\
album x post-2003 & & $(0.0564)$ & 0.1097 \\
& 2.2969 & 2.2957 & $(0.0586)$ \\
Constant & $(0.0891)^{* *}$ & $(0.0888)^{* *}$ & 2.2969 \\
& 923 & 923 & $(0.0889)^{* *}$ \\
Observations & 88 & 88 & 923 \\
Number of indices & & & 88 \\
\hline
\end{tabular}

Notes: Regression of log supply indices on indicators for albums post 1999 and albums post-2003. Standard errors in parentheses. All regressions include flexible time dummies that are common to albums and songs. Regressions are weighted by the number of works included in each index, divided by the number of years it covers. * significant at $5 \%$ level; ** significant at $1 \%$ level. 


\begin{tabular}{|c|c|c|c|c|c|}
\hline source & Era covered & $\begin{array}{c}\text { Date } \\
\text { released }\end{array}$ & reference & origin & songs? \\
\hline $\begin{array}{l}\text { Zagat } 1000 \text { Top } \\
\text { Albums of All } \\
\text { Time }\end{array}$ & -2003 (partial) & Sep 2003 & $\begin{array}{l}\text { Zagatsurvey Music Guide: 1,000 Top Albums of All Time (Zagat Survey: Music } \\
\text { Guide) } 2003\end{array}$ & USA & 0 \\
\hline $\begin{array}{l}\text { Pitchfork "Top } 200 \\
\text { Albums of the } \\
\text { 2000s" }\end{array}$ & $2000-09$ (partial) & Sep-09 & $\begin{array}{l}\text { http://pitchfork.com/features/staff-lists/7706-the-top-200-albums-of-the-2000s- } \\
\text { 200-151/ }\end{array}$ & USA & 0 \\
\hline $\begin{array}{l}\text { Pitchfork "Top } 500 \\
\text { Tracks of the } \\
\text { 2000s" }\end{array}$ & $2000-09$ (partial) & Aug-09 & $\begin{array}{l}\text { http://pitchfork.com/features/staff-lists/7685-the-top-500-tracks-of-the-2000s- } \\
\text { 500-201/ }\end{array}$ & USA & 1 \\
\hline $\begin{array}{l}\text { Pitchfork "Top } 100 \\
\text { Albums of the } \\
\text { 1990s" }\end{array}$ & 1990-1999 & Nov-03 & http://pitchfork.com/features/staff-lists/5923-top-100-albums-of-the-1990s/ & USA & 0 \\
\hline $\begin{array}{l}\text { Pitchfork "Top } 100 \\
\text { Albums of the } \\
\text { 1990s" }\end{array}$ & 1990-1999 & Oct-99 & http://web.archive.org/web/20010616215501/http://pitchforkmedia.com/top/90s/ & USA & 0 \\
\hline $\begin{array}{l}\text { NME Top } 100 \\
\text { Greatest Albums of } \\
\text { the Decade }\end{array}$ & $2000-09$ (partial) & Nov-09 & http://www.nme.com/list/albums-of-the-decade/158049/page/1 & UK & 0 \\
\hline $\begin{array}{l}\text { Metacritic All Time } \\
\text { High Scores (top } 50 \\
\text { pages) }\end{array}$ & $2001-2010$ (partial) & $\begin{array}{c}\text { Downloaded } \\
\text { October 8- } \\
15,2010\end{array}$ & http://www.metacritic.com/browse/albums/score/metascore/all?sort=desc & USA & 0 \\
\hline $\begin{array}{l}\text { Rolling Stone's } 500 \\
\text { Greatest Albums of } \\
\text { All Time }\end{array}$ & -2004 (partial) & April 2004 & http://www.rollingstone.com/music/lists/5702/31963 & USA & 0 \\
\hline $\begin{array}{l}\text { SPIN Magazine } \\
\text { "125 Best Albums } \\
\text { of the Past } 25 \\
\text { Years" }\end{array}$ & $1985-2010$ (partial) & Jul-10 & http://www.spin.com/spin25/125-best-albums-past-25-years & USA & 0 \\
\hline $\begin{array}{l}\text { A.V. Club Staff, } \\
\text { "The best music of } \\
\text { the decade." ( } 50 \\
\text { albums) }\end{array}$ & 2000-2009 (partial) & Nov-09 & http://www.avclub.com/articles/the-best-music-of-the-decade,35540/ & USA & 0 \\
\hline $\begin{array}{l}\text { Paste Magazine, } \\
\text { "The } 50 \text { Best } \\
\text { Albums of the } \\
\text { Decade (2000- }\end{array}$ & 2000-2009 (partial) & Nov-09 & $\begin{array}{l}\text { http://www.pastemagazine.com/blogs/lists/2009/11/the-best-albums-of-the- } \\
\text { decade.html }\end{array}$ & USA & 0 \\
\hline
\end{tabular}




\begin{tabular}{|c|c|c|c|c|c|}
\hline source & Era covered & $\begin{array}{l}\text { Date } \\
\text { released }\end{array}$ & reference & origin & songs? \\
\hline \multicolumn{6}{|l|}{ 2009)" } \\
\hline BestEver & $\begin{array}{l}\text { All time (top rated } \\
\text { albums) }\end{array}$ & $\begin{array}{c}\text { As of } \\
\text { October } 10, \\
2010 \\
\end{array}$ & http://www.besteveralbums.com/topratedstats.php?o=album & & 0 \\
\hline $\begin{array}{l}\text { One Thirty BPM } \\
\text { Top } 100 \text { albums of } \\
\text { the } 2000 \text { s }\end{array}$ & $2000-2009$ & Feb-10 & http://onethirtybpm.com/2010/02/15/the-top-100-albums-of-the-2000s/ & USA & 0 \\
\hline $\begin{array}{l}\text { Rate My Music top } \\
1000 \text { albums }\end{array}$ & All time & $\begin{array}{l}\text { As of Oct } \\
19,2010\end{array}$ & http://rateyourmusic.com/ & & 0 \\
\hline $\begin{array}{l}\text { Pitchfork "Top } 100 \\
\text { Albums of the } \\
1980 \text { s" }\end{array}$ & 1980-1989 & 20-Nov-02 & http://pitchfork.com/features/staff-lists/5882-top-100-albums-of-the-1980s/ & USA & 0 \\
\hline $\begin{array}{l}\text { Acclaimed Music } \\
\text { Singles (top 3000) }\end{array}$ & -2008 & Nov-08 & http://www.acclaimedmusic.net/ & & 1 \\
\hline $\begin{array}{l}\text { Acclaimed Music } \\
\text { Albums (top 3000) }\end{array}$ & -2009 & Nov-09 & http://www.acclaimedmusic.net/ & & 0 \\
\hline $\begin{array}{l}\text { Spinner Top } 50 \\
\text { Songs of the } 2000 \text { s }\end{array}$ & $2000-2009$ & 24-Nov-09 & http://www.spinner.com/2009/11/24/best-songs-2000s/ & Canada & 1 \\
\hline $\begin{array}{l}\text { One Thirty BPM } \\
\text { Top } 100 \text { Tracks of } \\
\text { the } 2000 \mathrm{~s}\end{array}$ & $2000-2009$ & $15-F e b-10$ & http://onethirtybpm.com/2010/02/15/the-top-100-tracks-of-the-2000s/ & USA & 1 \\
\hline $\begin{array}{l}\text { NME Top } 100 \\
\text { Tracks of the } \\
\text { Decade }\end{array}$ & $2000-2009$ & Nov-09 & http://www.nme.com/list/tracks-of-the-decade/158050 & UK & 1 \\
\hline $\begin{array}{l}\text { Blender } 500 \\
\text { Greatest Songs } \\
\text { Since You Were } \\
\text { Born }\end{array}$ & $1980-2005$ & Sept. 2005 & $\begin{array}{l}\text { http://www.blender.com/lists/68126/500-greatest-songs-since-you-were- } \\
\text { born.html }\end{array}$ & USA & 1 \\
\hline Q & $2000-2009$ & & www.qthemusic.com & UK & 0 \\
\hline FACT & 2000-2009 & & factmag.co.uk & UK & 0 \\
\hline Gigwise & $2000-2009$ & & gigwise.com & UK & 0 \\
\hline Gigwise & $2000-2009$ & & gigwise.com & UK & 1 \\
\hline Guardian, The & 2000-2009 & & guardian.co.uk & UK & 1 \\
\hline
\end{tabular}




\begin{tabular}{|c|c|c|c|c|c|}
\hline source & Era covered & $\begin{array}{c}\text { Date } \\
\text { released }\end{array}$ & reference & origin & songs? \\
\hline $\begin{array}{l}\text { The Line of Best } \\
\text { Fit }\end{array}$ & $2000-2009$ & & lineofbestfit.com & UK & 0 \\
\hline Mixmag & $2000-2009$ & & mixmag.net & UK & 0 \\
\hline musicOMH & $2000-2009$ & & musicomh.com & UK & 0 \\
\hline Resident Advisor & $2000-2009$ & & www.residentadvisor.net & UK & 0 \\
\hline Resident Advisor & $2000-2009$ & & www.residentadvisor.net & UK & 1 \\
\hline Rock's Back Pages & $2000-2009$ & & www.rocksbackpages.com & UK & 0 \\
\hline The Guardian & $2000-2009$ & & guardian.co.uk & UK & 0 \\
\hline The Sun & $2000-2009$ & & www.thesun.co.uk & UK & 0 \\
\hline The Sunday Times & $2000-2009$ & & sunday-times.co.uk & UK & 0 \\
\hline The Times & $2000-2009$ & & timesonline.co.uk & UK & 0 \\
\hline The Word & $2000-2009$ & & www.wordmagazine.co.uk & UK & 0 \\
\hline Times, The & $2000-2009$ & & timesonline.co.uk & UK & 1 \\
\hline Uncut & $2000-2009$ & & Uncut.co.uk & UK & 0 \\
\hline Virgin Media & $2000-2009$ & & virginmedia.com & UK & 0 \\
\hline Word, The & $2000-2009$ & & www.wordmagazine.co.uk & UK & 1 \\
\hline BET & $2000-2009$ & & bet.com & USA & 0 \\
\hline MSN.com & $2000-2009$ & & msn.com & USA & 0 \\
\hline $\begin{array}{l}\text { American } \\
\text { Songwriter }\end{array}$ & $2000-2009$ & & americansongwriter.com & USA & 0 \\
\hline Austin Town Hall & 2000-2009 & & austintownhall.com & USA & 0 \\
\hline BetterPropaganda & $2000-2009$ & & betterpropaganda.com & USA & 0 \\
\hline Billboard & $2000-2009$ & & billboard.com & USA & 0 \\
\hline Boom Box, The & $2000-2009$ & & theboombox.com & USA & 1 \\
\hline Boot, The & $2000-2009$ & & www.theboot.com & USA & 1 \\
\hline CokeMachineGlow & $2000-2009$ & & Cokemachineglow.com & USA & 0 \\
\hline Complex & $2000-2009$ & & complex.com & USA & 0 \\
\hline Complex & $2000-2009$ & & complex.com & USA & 1 \\
\hline
\end{tabular}




\begin{tabular}{|c|c|c|c|c|c|}
\hline source & Era covered & $\begin{array}{c}\text { Date } \\
\text { released }\end{array}$ & reference & origin & songs? \\
\hline $\begin{array}{l}\text { Consequence of } \\
\text { Sound }\end{array}$ & $2000-2009$ & & consequenceofsound.net & USA & 0 \\
\hline $\begin{array}{l}\text { Consequence of } \\
\text { Sound }\end{array}$ & $2000-2009$ & & consequenceofsound.net & USA & 1 \\
\hline Creative Loafing & 2000-2009 & & creativeloafing.com & USA & 0 \\
\hline Daily Californian & $2000-2009$ & & dailycal.org & USA & 0 \\
\hline Decibel & $2000-2009$ & & decibelmagazine.com & USA & 0 \\
\hline $\begin{array}{l}\text { Delusions of } \\
\text { Adequacy }\end{array}$ & $2000-2009$ & & Delusionsofadequacy.com & USA & 0 \\
\hline eMusic & $2000-2009$ & & emusic.com & USA & 0 \\
\hline $\begin{array}{l}\text { Entertainment } \\
\text { Weekly }\end{array}$ & $2000-2009$ & & ew.com & USA & 0 \\
\hline Ghostly & $2000-2009$ & & ghostly.com & USA & 0 \\
\hline Glide & $2000-2009$ & & glidemagazine.com & USA & 0 \\
\hline HipHopDX & $2000-2009$ & & hiphopdx.com & USA & 0 \\
\hline Kitsap Sun & $2000-2009$ & & kitsapsun.com & USA & 0 \\
\hline LostAtSea & $2000-2009$ & & www.lostatsea.net & USA & 0 \\
\hline Lost At Sea & $2000-2009$ & & www.lostatsea.net & USA & 1 \\
\hline Metromix Denver & $2000-2009$ & & & USA & 0 \\
\hline Noise Creep & $2000-2009$ & & www.noisecreep.com & USA & 1 \\
\hline $\begin{array}{l}\text { National Public } \\
\text { Radio }\end{array}$ & $2000-2009$ & & npr.org & USA & 0 \\
\hline NPR & $2000-2009$ & & npr.org & USA & 1 \\
\hline Popdose & $2000-2009$ & & popdose.com & USA & 0 \\
\hline Popdose & $2000-2009$ & & popdose.com & USA & 1 \\
\hline Rhapsody & $2000-2009$ & & rhapsody.com & USA & 0 \\
\hline Rhapsody & $2000-2009$ & & rhapsody.com & USA & 1 \\
\hline Rolling Stone & $2000-2009$ & & rollingstone.com & USA & 1 \\
\hline Rolling Stone & $2000-2009$ & & rollingstone.com & USA & 0 \\
\hline
\end{tabular}




\begin{tabular}{|c|c|c|c|c|c|}
\hline source & Era covered & $\begin{array}{c}\text { Date } \\
\text { released }\end{array}$ & reference & origin & songs? \\
\hline Slant & $2000-2009$ & & slantmagazine.com & USA & 0 \\
\hline Slant & $2000-2009$ & & slantmagazine.com & USA & 1 \\
\hline Stylus & $2000-2009$ & & thestylusdecade.com & USA & 1 \\
\hline Stylus Decade & $2000-2009$ & & thestylusdecade.com & USA & 0 \\
\hline The Boombox & 2000-2009 & & theboombox.com & USA & 0 \\
\hline Tiny Mix Tapes & $2000-2009$ & & tinymixtapes.com & USA & 0 \\
\hline Treble & $2000-2009$ & & Treblezine.com & USA & 0 \\
\hline Treble & $2000-2009$ & & Treblezine.com & USA & 1 \\
\hline Under the Radar & $2000-2009$ & & Undertheradarmag.com & USA & 0 \\
\hline Irish Times & $2000-2009$ & & www.irishtimes.com & Ireland & 0 \\
\hline State & $2000-2009$ & & www.state.ie & Ireland & 0 \\
\hline NOW & $2000-2009$ & & nowmusicforums.com & Canada & 0 \\
\hline Spinner & $2000-2009$ & & spinner.com & Canada & 0 \\
\hline
\end{tabular}

